NBER WORKING PAPER SERIES

\title{
THE U.S. CONSTITUTION AND MONETARY POWERS: AN ANALYSIS OF THE 1787 CONSTITUTIONAL CONVENTION AND HOW A CONSTITUTIONAL TRANSFORMATION OF THE NATION'S MONETARY SYSTEM EMERGED
}

\author{
Farley Grubb \\ Working Paper 11783 \\ http://www.nber.org/papers/w11783 \\ NATIONAL BUREAU OF ECONOMIC RESEARCH \\ 1050 Massachusetts Avenue \\ Cambridge, MA 02138 \\ November 2005
}

The author is Professor of Economics and NBER Research Associate, University of Delaware, Newark, DE 19716 USA. E-mail: grubbf@lerner.udel.edu. The author thanks an anonymous correspondent on a related project and discussions with Christine Desan for planting the seeds of the current paper and thanks the editor and referees for this journal and Howard Bodenhorn for helpful comments on an earlier draft. Financial support provided by a 2003-2004 American Philosophical Society Sabbatical Fellowship Grant, resource support provided by Harvard University Department of Economics, research assistance provided by Eric O'Connor, and editorial assistance provided by Tracy M. Cass and Anne Pfaelzer de Ortiz are gratefully acknowledged. The views expressed herein are those of the author(s) and do not necessarily reflect the views of the National Bureau of Economic Research.

(C2005 by Farley Grubb. All rights reserved. Short sections of text, not to exceed two paragraphs, may be quoted without explicit permission provided that full credit, including $(\odot)$ notice, is given to the source. 
The U.S. Constitution and Monetary Powers

Farley Grubb

NBER Working Paper No. 11783

November 2005

JEL No. K10, G20, E50, N21, H10

\title{
ABSTRACT
}

The monetary powers embedded in the U.S. Constitution were revolutionary and led to a watershed transformation in the nation's monetary structure. They included determining what monies could be legal tender, who could emit fiat paper money, and who could incorporate banks. How the debate at the 1787 Constitutional Convention over these powers evolved and led the Founding Fathers to the specific powers adopted is presented and deconstructed. Why they took this path rather than replicate the successful colonial system and why they codified such powers into supreme law rather than leaving them to legislative debate and enactment are addressed.

\author{
Farley Grubb \\ University of Delaware \\ Economics Department \\ Newark, DE 19716 \\ and NBER \\ grubbf@lerner.udel.edu
}




\section{The U.S. Constitution and Monetary Powers: An Analysis of the 1787 Constitutional Convention and And How a Constitutional Transformation of The Nation's Monetary System Emerged*}

In 1787, just over three years after the Treaty of Paris recognized U.S. independence, the founding fathers met from May 25th through September 17th in Philadelphia to craft a new national constitution to replace the Articles of Confederation. ${ }^{1}$ This new U.S. Constitution, ratified by the states and then adopted by Congress in 1789, profoundly altered the nation's monetary structure. It was nothing short of revolutionary (Ferguson 1983, 404-405). Before the U.S. Constitution, the principal "inside" paper money in circulation was issued directly by government legislatures and backed not by specie (the "outside" money of the times) but by the issuing government's future taxes. ${ }^{2}$ Very few banks existed—none before 1782 and only three by 1787. After the U.S. Constitution, governments were prohibited from issuing paper money. Instead, government chartered, but privately run and largely unregulated, banks proliferatednumbering 76 by 1805 —and filled the inside paper money void by issuing banknotes backed by fractional reserves in specie. By banning the chief alternative competitor, the U.S. Constitution established the legal framework that allowed for the ascendance in the U.S. of the modern bank-based financial system.

The constitutional monetary powers of interest are defined here as 1) the power to emit bills of credit — paper money, 2) the power to determine what money is legal tender, and 3) the power to charter banks. These powers focus on restructuring the means of payment in society by circumscribing the money supply. The Constitution did not directly or legally force a common monetary unit of account or medium of exchange onto 
the nation. Post-Constitution, a plethora of different private banknotes and specie coins in different foreign measurement units circulated as currency. The Constitution at best circumscribed the medium of exchange to being specie and specie-linked paper substitutes. A common monetary unit of account — the U.S. Dollar-would emerge as a by-product of the market's optimal transactions-cost adjustment to the restructured means of payment brought about by the Constitution. ${ }^{3}$

At the Constitutional Convention the founding fathers decided by explicit vote not to include the power to emit bills of credit and (debatably) not to include the power to charter banks among the powers granted to the national government. ${ }^{4}$ They decided to prohibit individual states absolutely from emitting bills of credit and from having power to determine what could be legal tender, i.e. Article 1, Section 10 of the U.S. Constitution states, "No State shall...coin Money; emit Bills of Credit; make any Thing but gold and silver Coin a Tender in Payment of Debts..." Finally, the founding fathers did not take away the power to charter banks from the states. These decisions embedded in simple Constitutional clauses and Convention votes radically transformed the nation's monetary structure.

These decisions, however, did not emerge until rather late in the Convention's deliberations. What emerged was not an obvious choice before or up through the first half of the Convention. Thus, these decisions were not only revolutionary in their impact but arguably were somewhat unexpected. Why mid-Convention did the founding fathers shift gears and opt for something both new and radically different from what went before?

Colonial America had experienced stable fiat paper money regimes (Ferguson 1969, 249; 1983, 404; Grubb 2003, 2004; Perkins). Why didn't the founding fathers replicate that 
system? How did they go from a quarter-century experience of stable paper money regimes before the Revolution to a total Constitutional ban on paper money at all levels of government after 1787? The evolution of the debates and decisions at the Convention may be important to our understanding of what emerged. And because of what emerged, these debates may also be informative of larger political economy issues that are still studied today regarding the role of money creation in financing wars, the costs and benefits of public versus private inside money supply systems and, given a private inside money supply system, what degree of political independence these suppliers should be granted and whether they should be regulated.

The primary purpose of the analysis that follows is to trace and deconstruct the "what" and "how" of this dramatic, constitutionally manufactured transformation of governmental monetary powers as they evolved during the Constitutional Convention. ${ }^{5}$ These powers were not a reason why the Convention was called. They were not issues at the 1785 Mount Vernon Conference or at the 1786 Annapolis Convention, nor were they issues in the numerous amendments to the Articles of Confederation from 1781 through 1786 (Grubb 2003, 1789; Jensen I, 140-229; Rutland II, 814-822). The primary reasons given for calling the Convention were to solve trade and navigation disputes between the states and to secure an independent source of tax revenue for the national government. By giving the national government independent power to raise tax revenue and regulate trade between the states, the structural allocation of power among the states within the national government became a paramount concern and occupied most of the Convention's time. However, the issue of monetary powers, like the issues of slavery and curbing the 
excesses of democracy, became one of the prominent subtexts of the Convention (Ferguson 1969; 1983).

The analysis begins with Section $\mathbf{I}$ establishing the monetary and economic conditions leading into the Convention to determine what economic problems and monetary conditions the founding fathers faced. The key economic problems were trade depression, price deflation, and acute specie scarcity, and the key monetary problem was the extensive use of legal tender laws by the states.

Sections II through VI trace the evolution of monetary powers considered and arguments offered by the delegates chronologically through the Convention from its beginning on May 29th to its conclusion on September 17th. Several important theses emerge here. First, replicating the colonial monetary system appears to be the initial tack taken at the Convention. The monetary powers actually adopted do not emerge until quite late at the Convention. Second, a pervasive, escalating, and perhaps intentional conflation of legal tender problems with emitting paper money per se takes place in Convention rhetoric. Third, while not in the written Constitution, the Convention voted to disallow federally issued paper money. Fourth, the Convention appeared also to disallow federally chartered banks. Fifth, the post-Convention controversy over a federally chartered bank was not about the application of the Constitution's implied-powers clause.

Finally, Sections VII-VIII use the foregoing analysis to evaluate why the founding fathers acted as they did regarding the monetary powers put into the Constitution. Many of the common arguments in the literature are dismissed as inconsistent with the totality of the Convention debates. A new explanation will be 
offered dealing with creating a specie reservoir in society. The outline of the analysis is as follows:

I. The American Monetary Regime Leading into the Constitutional Convention, 1750-1787

A. Colonial Legislature-issued Tax-backed Fiat Paper Money Regimes and Their Regulatory Constraints

B. The Revolution and Paper Money

C. The Economy and State Paper Money between the Treaty of Paris and the Adoption of the Constitution

D. The Problem of Legal Tender Laws versus Paper Money Emissions Per Se

E. Did the Founding Fathers Distinguish Between Legal Tender Laws and Paper Money Per Se?

II. The Beginnings-May 29 to July 26: The Virginia Plan, its Modifications, and Rivals

A. The Randolph Opening

B. In the Shadows-The Pinckney Plan

C. Debating and Amending the Virginia Plan-May 30th through July 26th

\section{Paper Money Riot Interlude?}

IV. The Committee of Detail—July 27 to Aug. 6: The Initial Restructuring of Monetary Powers

V. The End Game-Aug. 6 to 28: The Absolute Constitutional Proscription of Monetary Powers

A. The Absolute Prohibition on Paper Money Issued by the National Government 
B. The Absolute Prohibition on Paper Money Issued by State Governments

VI. National Banking as a Substitute Monetary Power?-Aug. 28 to Sept. 14

A. Who Shall Have the Power to Charter Banks?

B. The Post-Convention Constitutional Controversy over Who Can Charter Banks

\section{Why Did They Do It?}

A. Rent-Seeking Bankers?

B. Big Tents, Polarization, Insider Speculation, and Income/Debt Redistribution Schemes?

C. Creating a Specie Reservoir in Society for the Merchant Community Involved in International Trade?

\section{Epilogue}

\section{The American Monetary Regime Leading into the Constitutional Convention,} 1750-1787

A. Colonial Legislature-issued Tax-backed Fiat Paper Money Regimes and Their Regulatory Constraints

The British North American colonies were the first modern western economies to experiment with large-scale government issuances of fiat paper money. Colonial legislatures directly issued bills of credit to pay for their government's expenses and as mortgage loans to subjects who pledged their lands as collateral. These bills were not government bonds. Typically, they earned no interest, came in small denominations, circulated at market-determined rates of exchange to specie and the paper monies of other colonies, and were accepted by the issuing government in payment of that government's fees and taxes. Colonial governments never redeemed on demand their paper money for 
specie nor entered the market at their discretion to buy and sell their paper money for specie to defend a fixed exchange rate. These bills circulated inside, but seldom outside, the colony of issue as cash alongside specie monies, which only entered and exited the colony through merchant foreign trade and government transfers. Payments to parties outside the colony were typically in specie units. By the middle of the 18th century, these bills comprised a substantial portion of the money supply within their respective colonies. Colonial legislatures backed their paper money by linking it not to specie but to future taxes and mortgage payments designed to withdraw it from circulation in a timely fashion. Upon redemption, it was burned. Each colony maintained the market value of its paper money through its timely injection and then redemption, thereby controlling the quantity of paper money in circulation. The presence of competitive currency substitutes (specie) constrained colonies to follow a stable path with regard to the relative value of their inside paper monies (Brock; Ferguson 1969, 249; 1983, 399, 404; Grubb 2003, 2004, 2005a; Perkins; Priest; Smith 1985).

The British government extended the Bubble Act to the colonies in 1741effectively eliminating banks - and imposed regulations on paper money with the Currency Acts of 1751 and 1764. The Currency Acts allowed the colonies to emit paper money as long as it met two requirements, namely 1) that it not be made a legal tender and 2) that ample taxes be put in place to redeem each issue in a reasonable time. Some colonies had instituted such policies on their own accord long before these regulations were passed. After 1748, unlike most other colonies, Massachusetts renounced paper money and returned to the specie standard for the rest of the colonial period. While paper money could not be made a legal tender for all debts, it was always accepted in payment 
for the issuing government's taxes and so it became a de facto legal tender for public debts in the issuing government's jurisdiction. This in turn provided the anchor that allowed the bills to circulate as cash within that colony. By 1750 colonial legislatures had learned, for the most part, how to handle their tax-backed paper money regimes. This colonial monetary system produced remarkable long-run stability in terms of low inflation rates and stationarity in prices, exchange rates, and purchasing power parity (Behrens; Bordo and Marcotte; Brock; Ferguson 1969, 249; 1983, 399, 404; Grubb 2003, 2004, 2005b; Perkins; Pickering XX, 306-309; Priest; Smith 1985).

The two regulatory pillars that made this colonial monetary system work were 1) that paper money could not be made a legal tender (other than for paying taxes levied by the issuing government), and 2) that the issuing government credibly commit, by enacting taxing policies concurrent with issuing said paper money, to redeeming its paper money in a timely fashion. Most of the founder fathers had lived and prospered as adults under this regulatory system.

\section{B. The Revolution and Paper Money}

This system continued through the Revolution. Under the Articles of Confederation both individual states and the Continental Congress issued their own taxbacked paper money. Beginning in 1775 the Continental Congress issued bills of creditContinental dollars - that depreciated to near zero and ceased to circulate after April 1781 (Bezanson 1951; Calomiris; Rockoff 14-42). Without the power to levy its own taxes, Congress under the Articles of Confederation could not credibly commit to redeeming its bills of credit. This structural flaw along with the exigencies of wartime finance and doubts about the legitimacy of the Revolutionary government were the likely sources of 
the monetary troubles behind the Continental dollar, not just the emission of paper money per se. The Treaty of Paris resolved the issue of legitimacy and wartime financial pressure. And one of the primary goals of the 1787 Constitutional Convention was to correct the structural flaw by giving the national government an independent source of revenue by granting it the direct power of taxation. This in turn would let Congress credibly commit to redeeming its bills of credit and so potentially solve the national government's paper money problems.

Each of the 13 colony/states also issued its own paper money during the Revolution that, while depreciating, held its value to a greater extent than did the Continental dollar, in part because states had the power to tax and so could credibly back their currencies. The overwhelming cost of financing the war and the net specie export drain caused by wartime trade disruptions swamped their ability to fully tax-back their currencies and prevented their currencies from holding at par with specie (Nettels 1-44). C. The Economy and State Paper Money between the Treaty of Paris and the Adoption of the Constitution

After the collapse of the Continental dollar in 1781, the national government did not return to issuing fiat paper money. While all states had issued paper money during the Revolution, new issues were rarer post-Revolution. Within three years of signing the Treaty of Paris, 7 of the 13 states-Pennsylvania, North Carolina, and South Carolina in 1785; Rhode Island, New York, New Jersey, and Georgia in 1786 —returned to issuing new amounts of their own paper money usable, as during the colonial period, to pay taxes levied and land mortgages held by the issuing state. State legislatures in Virginia, Maryland, New Hampshire, and Massachusetts were also debating whether or not to issue 
new bills of credit (Grubb 2003; Holton 2005a, 198). States were considering such

measures because of the substantial post-Revolution trade depression that devastated their economies between 1782 and 1790 . The problem facing the U.S. and the founding fathers in the half decade leading up to the Constitutional Convention was not inflation, but deflation, and serious deflation at that, caused by a temporary but sharp and substantial trade deficit that drained foreign reserves (specie) out of the economy (Holton 2005b; Nettels 45-64, 105).

Some founding fathers wrote as if they knew this. James Wilson, Convention delegate from Pennsylvania and a major architect of the monetary powers adopted at the Convention, explained in 1785:

The disagreeable state of our commerce has been the effect of extravagant and injudicious importation. ... When hostilities ceased, the floodgates of commerce were opened; and an inundation of foreign manufactures overflowed the United States: we seemed to have forgot, that to pay was as necessary in trade as to purchase; and we observed no proportion between our imports, and our produce and other natural means of remittance. What was the consequence? Those who made any payments [to foreigners] made them chiefly in specie; and in that way diminished our circulation (Adams 145).

Likewise, James Madison, Convention delegate from Virginia and one of the major architects of the overall Constitution, remarked in a letter to Thomas Jefferson dated March 18, 1786 that:

Another unhappy effect of a continuance of the present anarchy of our commerce, will be a continuance of the unfavorable balance on it, which by draining us our metals furnishes pretexts for the pernicious substitution of paper money, for indulgences to debtors, for postponement of taxes. In fact most of our political evils may be traced up to our commerce ones,... The lessons which the merchantile interest of Europe have received from late experience will probably check their propensity to credit us beyond our resources, and so far the evil of an unfavorable balance will correct itself. But the merchants of G.B. [Great Britain] if no others will continue to credit us at least as far as our remittances can be strained, and that is far enough to perpetuate our difficulties unless luxurious propensity of our people can be otherwise checked. This view of our situation 
presents the proposed Convention as a remedial experiment which ought to command every assent... The price of our Staple is down....[and the] price has notwithstanding been falling ever since. ... The scarcity of money must of necessary sink the price of every article (Rutland 1973 VIII, 502-503).

Alexander Hamilton, Convention delegate from New York and another of the major architects of the nation's monetary powers, from 1781 through 1790 frequently alluded to the scarcity of specie in circulation in the U.S. and fretted over ways to correct this scarcity by creating a money that was a near-perfect substitute for specie but also was not prone to the same problem as specie, namely temporary shortages caused by trade shocks that sent specie (or its perfect substitutes) out of the country (Syrett II, 618-619; III, 104, 175; VI, 71-72). Finally Gouverneur Morris, Convention delegate from Pennsylvania and a major architect of the monetary powers adopted at the Convention, observed during the Convention that "For a long time the people of America will not have money [meaning specie] to pay direct taxes" (Farrand II, 307). Similar statements indicating an awareness of this economic situation appeared in the popular press and writings of other prominent people (Holton 2005b).

Price indices also show that from the end of the Revolutionary War in 1783 through the adoption of the U.S. Constitution in 1789 the U.S. suffered significant price deflation (Grubb 2003, 1782-1783). For example, the Philadelphia price index fell 18 percent, the Charleston, South Carolina, price index fell 20 percent, and the New York City price index fell at least 6 percent (Bezanson 1936, 392; Cole 121-122, 156). Price indices were denominated in their respective state paper currencies. When prices are declining, the currency is appreciating, namely more real goods can be purchased with a given nominal amount of currency. Yet the post-Revolution rhetoric of many founding 
fathers and most scholarship to this day says that state paper money was depreciating in this period. How is that possible given price deflation?

The answer is that when contemporaries talked about the value of state paper money it was not in terms of the real goods that it could purchase but in terms of how much specie (foreign exchange) it could buy. State paper money appreciating in terms of real goods but depreciating in terms in specie implies that specie was getting increasingly scarce relative both to goods and paper money. This is consistent with a massive shortrun unexpected trade deficit temporarily draining specie overseas. In other words, the specie price of goods in the U.S. between 1783 and 1789 (if we had such data) must have been falling even faster than the paper money price of goods. The implication is that to have an "undepreciating" paper currency in terms of specie in this period would have necessitated an even greater price deflation and so an even deeper recession than what occurred. The problem was not with state paper money per se, but with foreign trade and specie. In fact, the states that stepped in to issue paper money post-Revolution can be seen as trying to stem the price collapse due to the collapse of the specie money supply by providing temporary needed liquidity to support at least domestic exchange (Holton 2005b).

The key difference between the colonial system and this latter state system of paper money, with a few notable exceptions, was the extensive use of legal tender laws. This was caused by the exigencies of wartime finance (inflationary pressures caused by excessive emission of paper money relative to the taxing base), its immediate aftermath (immediate post-war pressures to quickly service this war debt), and the trade recession that led to a net drain of specie out of the economy (Holton 2004, 2005b; Nettels 23-88). 
Legal tender laws were price controls, and wars and their immediate aftermath have often necessitated some type of price-control exercise (Rockoff).

\section{The Problem of Legal Tender Laws versus Paper Money Emissions per se}

The legal profession's definition of "legal tender"- that a person can be compelled via legal sanctions to accept particular monies in payment of debt—is largely irrelevant in terms of the economic impact of tender laws if said monies are competitively priced in the marketplace. Under such conditions the receiver is indifferent between accepting said money and any other market equivalent value (sans the minor issue of transacting costs). The receiver would just proceed to the market and exchange his legal tender money for what was contracted for or really desired in the initial exchange with little loss of value.

Legal tender laws have economic impact when the said tender is not competitively priced in the marketplace, typically due to government imposed price or exchange rate controls that artificially peg the value of the tender above its market value. To distinguish this condition from the legal profession's generic understanding of legal tender, it will be called here "binding legal tender." Under such conditions a person legally compelled to receive the tender in payment of a debt receives less than its market equivalent in other goods or monies. As such, this person is no longer indifferent between receiving the tender and receiving payment in an alternative form or in what was initially contracted as payment-preferring the alternative to the legal tender. It is the binding legal tender problem that the founding fathers faced.

In the Colonial and early Republican periods legal tender laws implied binding legal tender. Most colony/state bills of credit had a par relationship to specie-either to 
Spanish dollars or pounds sterling, e.g. 1.33 Maryland pounds being par to one poundssterling (McCusker; Smith 1985). The par rate was the rate at which the issuing government typically committed to receiving its paper money in payment of its taxes. Without a legal tender law, the rate of exchange in the marketplace could vary from the par rate, and thus little damage to contracting would occur in that real transaction values would be equivalently priced across different monies. If, however, the issuing government declared its paper money to be a legal tender for all debts, then the pressure was to accept it at its par rating to its specie counterpart. Because this legal expedient was typically used during wartime emergencies and/or periods when a temporary unexpected dearth of specie forced paper money to depreciate in terms of how much specie it could buy, it meant being legally forced to accept paper money at considerably more than its market-determined value in specie. This was a form of price or exchange rate control. The Revolution might not have been successfully fought and financed without some product price, currency price, and/or exchange rate control (Farrand II, 309; Rockoff). Such controls, however, could only function as short-run stopgap measures. They could not be successful for very long. Many of the founding fathers wrote as if they understood this - namely that legal tender laws were a separate issue from paper money emissions per se (see Section I. E. below).

The financial pressures in the immediate aftermath of the Revolution led several states to declare their new paper money to be a binding legal tender with Rhode Island being the most notorious (Bishop; Holton 2004). Rhode Island will be used to illustrate important features of the post-Revolution finance problem. Like many states, Rhode Island had issued both paper money and debt (bonds) during the Revolution, well beyond 
the state's near-term tax revenue capacity. The result was depreciation of both instruments. The risk of the state defaulting on its bonds, and the immediate post-war depression allowed some wealthy merchants to buy up these bonds at a price far below their specie face value, such as at 8 to 1 . After having bought up these bonds at huge discounts, these same people in their position as, or influence over, state legislators were suspected of being the force behind getting the state to raise taxes in specie substantially so that the state could pay off the bonds at face value in specie. The proposed increase in specie taxes, in a depressed economy with little specie inflow due to trade disruptions, threatened to bankrupt many Rhode Island citizens and force them to sell off their property at fire-sale prices, thus further enriching those with resources and credit to buy.

Rhode Island voters stopped this suspected "insider-trading" speculative scheme through defeating those involved at the polls. This was an example of the "excesses" of democracy that some Federalists carped about. The new legislators ended the potential for any such scheme in the future through a new paper money emission in 1786 . This emission was made a legal tender specifically for the purpose of forcing holders of Rhode Island war bonds to exchange them at face value for this new paper money. Given that the fiscal capacity of the state had not yet recovered, the taxing provisions in place were not sufficient to support this new paper money and so it also depreciated, though not necessarily below the market price of the war bonds. Merchant-speculators in war bonds who were seeking a payoff in specie from the state so they could cover payments outside the state were suddenly forced to take that state's inside paper money at par. In the marketplace they could not convert this paper money into specie at the same war bond face value, thus their ability to cover outside money transactions was threatened. 
Much of the rhetoric at the time of the Convention (and even to this day) that singled out Rhode Island as the poster-child for irresponsible state management of paper money was written by the side that had its insider-trading get-rich speculation scheme dashed by the "excess" of democracy in Rhode Island. Something similar to this scheme was likely tried in Massachusetts with Shay's Rebellion being its major outcome. As shown throughout the rest of the study below, many of the founding fathers wrote as if they knew and understood that the core problems were short-term war finance, post-war trade depression, and the resulting binding legal tender laws, and not paper money per se (see also Bishop; Farrand II, 307, III, 214-215; Grubb 2003, 1789-1790; Holton 2004; Jensen III, 301-302; Perkins).

E. Did the Founding Fathers Distinguish Between Legal Tender Laws and Paper Money per se?

The founding fathers wrote as if they understood the difference between binding legal tender laws and the emission of paper money per se. Most had lived and commercially prospered before the Revolution under colonial paper money regimes. For them to have been unaware of British regulations regarding legal tender status versus paper money per se would seem unlikely. In addition, this awareness can be seen in their writings. Roger Sherman, Convention delegate from Connecticut, writing as far back as 1752, and Peyton Randolph, uncle and role model to Edmund Randolph, Convention delegate from Virginia, writing as far back as 1759, recognized the difference between binding legal tender laws and the emissions of paper money per se (Bradford 22, 166; Philoeunomos; Randolph). 
The distinction between binding legal tender laws and the emission of paper money per se was also made by many founding fathers shortly before the Convention. For example, William Paterson, Convention delegate from New Jersey, wrote in 1786, "An increase of paper money if it be a tender, will destroy what little credit is left; will bewilder conscience in the maze of dishonest speculations; will allure some and constrain others into perpetuation of knavish tricks, will turn vice into legal virtue; and will sanctify iniquity by law." (Warren 551 [italics added]). The debate in the New Jersey Gazette on 30 January 1786 focused on the difference between a non-legal-tender and a binding-legal-tender paper money, the latter being bad. New Jersey nevertheless made its 1786 emission of paper money a legal tender.

In his address to the New York Assembly in February of 1787, just a few months before the Convention, Hamilton pointed out the potential inequities across states that would arise if states paid their share of Federal taxes in their respective state paper monies. In effect, binding legal tender laws would allow states with higher paper money depreciation rates to pay less tax in specie equivalents than states with lower paper money depreciation rates (Syrett IV, 87; footnote 8 below). ${ }^{6}$ Hamilton's logic presumes that the problem is binding legal tender laws and not the emission of paper money per se.

Similarly, in a letter written April 15, 1787 just a month before the Convention, Benjamin Franklin, Convention delegate from Pennsylvania, commented, "What you mention of our paper money, if you mean that of this State, Pennsylvania, is not well understood. It was made before my arrival [1785], and not being a legal tender can do no injustice to anybody nor does anyone here complain of it, though many are justly averse to an increase of the quantity at this time,..." Likewise, in a letter to George Mason, 
Convention delegate from Virginia, dated May 15, 1787, Richard Henry Lee wrote, "Knaves assure, and fools believe, that calling paper 'money' and making it a tender is the way to be rich and happy: thus the national mind is kept in continual disturbance by the intrigues of wicked men for fraudulent purposes, for speculative designs." (Smyth IX, 561; Warren 551-52 [italics added]; see also Rutland 1970, 861).

Finally, many of the anti-paper-money statements made by the founding fathers before, during, and after the Convention focused not on inflation (the over-issue of paper money per se) but on the "fraud" and "injustice" caused when a paper money was made a binding legal tender (e.g. Farrand III, 350; Jensen III, 141, 402). For example, in the ratification debates in Pennsylvania shortly after the Convention, Wilson remarked, "It is true we have no tender law in Pennsylvania; but the moment you are conveyed across the Delaware [into New Jersey] you find it haunts your journey and follows close upon your heels. The paper [in New Jersey] passes commonly at twenty-five or thirty percent discount. How insecure is property!" (Jensen II, 500 [italics added]).

In conclusion, many founding fathers wrote as if they understood the distinction between binding legal tender laws and paper money emissions per se, and that the former and not the latter was the source of the monetary problems at hand. It is true that many of the founding fathers, both pro- and anti-federalists, had made generalized anti-paper money statements both prior to and after the Convention, e.g. Madison, Hamilton, Mason, Robert Morris, etc. (Grubb 2003, 1781). This is not surprising given the debacle of the paper Continental dollar during the Revolution and the continuing post-war efforts by the states to refinance their wartime debts and stem the post-war depression by issuing new paper money with the frequent use of binding legal tender laws. But it is one thing to 
be against current monetary policy and the use of binding legal tender laws, suffer angst over particular choices made by democratic legislatures, and engage in debate over what the best current legislative policy should be, and quite another thing to make the leap to enshrining absolute monetary restrictions into the supreme law of a constitution. How did the founding fathers during the Convention make that leap?

\section{The Beginnings-May 29 to July 26: The Virginia Plan, its Modifications, and}

\section{Rivals}

\section{A. The Randolph Opening}

The Convention began in earnest on May 29th with an address by Edmund Randolph of Virginia. Speaking for the Virginia delegation he presented, in order, the following: 1) the characteristics that a proper government ought to have, 2) the defects of the Articles of Confederation, 3) the present dangers being faced, and 4) a remedy in the form of a new plan of government embodied in 15 resolutions - traditionally known as the Virginia Plan (Farrand I, 15-28; III, 593-594). In assessing the defects of the Articles of Confederation Randolph praised its authors but noted that certain problems could not have been foreseen by them, one of these being that in 1776 the "...the havoc of paper money had not been foreseen..." Randolph's choice of words without further need of elucidation would be consistent with a common understanding among the delegates that the paper money emissions of the colonial governments prior to the Revolution had not caused havoc. In other words, fiat paper money per se was not the problem.

When Randolph turned to his remedy, the Virginia Plan of government, he presented no specific resolution or words touching directly on paper money. However, Resolution 6 of the plan proposed to give the national government new general powers 
that could potentially be applied to monetary issues, namely “...the National Legislature ought to be impowered...to legislate in all cases to which the separate States are incompetent, or in which the harmony of the United States may be interrupted by the exercise of individual Legislation; to negative all laws passed by the several States, contravening in the opinion of the National Legislature the articles of Union..." Deciding what monies could be a legal tender in exchange across states and with the national government would appear to fall within this new power. But as long as a state did not make its paper money a legal tender for anything other than the payment of that state's taxes (making it a within-the-state inside money only), then such paper money emissions would appear to be untouchable by national legislation. Such paper money would not "contravene...the articles of Union" nor would the "harmony of the United States...be interrupted by this exercise of individual [state] Legislation..." In essence, this can be interpreted as potentially restoring one pillar of British monetary oversight of the colonies, namely that individual states would be allowed to issue paper money as long as it was not made a legal tender. That Resolution 6 of the Virginia Plan as strictly worded potentially empowered Congress to ban state paper money emissions per se seems doubtful. $^{7}$

Finally, Resolution 6 would also appear to give the national legislature the power to issue its own national paper currency. Given that one of the new powers to be given the national legislature was the ability to directly tax and collect revenue independent of the states (perhaps the single most important new power sought), the problem of the inability of the national government to redeem its paper money emissions in a timely fashion through national taxation was removed. In other words, the key structural 
problem that led to the Continental dollar fiasco during the Revolution would be resolved. In essence, the new powers embodied in the Virginia Plan can be interpreted as potentially restoring part of another pillar of British monetary oversight of the colonies, namely that fiat paper money (on the national level) should be adequately backed by future taxes. It is difficult to interpret the Virginia Plan as going beyond just reestablishing the colonial monetary system — adding the powers and constraints needed for its success.

\section{B. In the Shadows-The Pinckney Plan}

At the end of the same day that Randolph presented the Virginia Plan, Charles Pinckney of South Carolina read his plan of government to the Convention. The speech Pinckney made and his plan of government were not recorded by anyone, though Madison wrote that along with the Virginia Plan, Pinckney's Plan was “referred to the Committee of the whole [the entire Convention]..." And Robert Yates of New York wrote that Pinckney "...confessed that it [his plan] was grounded on the same principle as of the above resolutions [the Virginia Plan]" (Farrand I, 16, 23, 24). Over the next two months the Convention debated the details of the Virginia Plan, using it as the edifice for constructing a new plan of government. The Pinckney Plan disappeared into the shadows. It was never directly debated by the Convention. However, given that the Pinckney Plan appears to re-emerge after July 26th in the Committee of Detail and have an impact on that Committee's reshaping of the amended Virginia Plan on monetary issues, it is important to reconstruct Pinckney’s May 29th speech and plan with regard to monetary powers. 
After the Convention Pinckney published a pamphlet purporting to be the speech he delivered at the opening of the Convention. How much of this material comprises additions and deletions after the fact is hard to say and is a caveat to keep in mind (Farrand III, 106-123, 595-609). Pinckney argued that the national Congress should have the power both to revise and negate any state laws that appear to the national Congress as improper. Pinckney wrote, "The proceedings of the States which merely respect their local concerns, will always be passed [by the national congress] as matters of form, and objections only arise where they shall endeavor to contravene the Federal Authority" (Farrand III, 112-115). While this statement gives broader power over state laws than the Virginia Plan, on monetary issues it would appear to lead to the same outcome as the Virginia Plan. The national government could not stop states from issuing a non-legaltender inside paper money because that would be a purely local concern, but the national government could stop states from making their paper money a legal tender particularly with regard to its use in outside-money transactions (payments across-states and to the National Treasury).

Pinckney also wrote that the national government should have, "The exclusive right of...determining in what species of money the common Treasury shall be supplied... If you allow the States to...emit Bills of Credit, they will force you to take them in payment for Federal Taxes and Duties,... and though, Congress may determine, that nothing but Specie shall be received in payment of Federal Taxes or Duties, yet, while the States retain the rights they at present possess, they will always have it in their power, if not totally to defeat, yet very much to retard and confuse the collection of Federal Revenues. ... There can be no other mode of ascertaining this, than to give to the 
United States the exclusive right of coining, and determining in what manner the Federal Taxes shall be paid" (Farrand III, 117-118). This statement argues that the national government should have power to prevent states from making their paper monies legal tender with regard to payments to the national government. ${ }^{8}$

In the second sentence quoted above Pinckney would appear to be suggesting that state emissions of paper money be banned outright. However, reading the key elements of the passage more closely suggests that that is not the case, namely "If you allow the States to...emit Bills of Credit, they will force you to take them...[as long as] the States retain the rights they at present possess..." The only relevant other "right" Pinckney could be referring to at the end of this passage (he explicitly mentions emitting bills of credit at the outset of the passage) is a state's right to declare its paper money a legal tender. It is the state's legal tender power that is the source of mischief, not the emission of paper money per se. This interpretation is consistent with why Pinckney only proposes that the national government be given the power to determine "in what manner Federal Taxes shall be paid" and makes no proposal to ban state emissions of paper money. (See also the interpretation in Farrand III, 604-607).

However, in the Pinckney Plan that was among the papers of the Committee of Detail there is no mention of any national government power to determine "in what manner Federal Taxes shall be paid" or anything related explicitly to paper money or legal tender laws. Only the following related clause appears: "Each State retains its Rights not expressly delegated-But no Bill of the Legislature of any State shall become a law till it shall have been laid before S. \&. H. D. in C. [Senate and House of Delegates in Congress] assembled and received their Approbation" (Farrand II, 134-137). And a 
clause similar to this in the Virginia Plan was voted removed by the Convention prior to turning their deliberations over to the Committee of Detail.

C. Debating and Amending the Virginia Plan-May 30th through July 26th

From May 30th through July 26th the Committee of the Whole (the entire Convention) debated and amended the Virginia Plan, including hearing rival plans. Monetary powers, while not directly addressed, remained a subtext in these debates and played a role in defining the future path taken.

On May 31st Resolution 6 of the Virginia Plan was debated. Regarding the clause "the National Legislature ought to be impowered...to legislate in all cases to which the separate States are incompetent...” Pinckney and John Rutledge of South Carolina "objected to the vagueness of the term incompetent, and ...[wanted to] see an exact enumeration of the powers comprehended by this definition." Randolph "disclaimed any intention to give indefinite powers to the national Legislature, declaring that he was entirely opposed to such an inroad on State jurisdictions..." Wilson "observed that it would be impossible to enumerate the powers which the federal Legislature ought to have." Finally, Madison "said that he had brought with him into the Convention a strong bias in favor of an enumeration and definition of powers necessary to be exercised by the national Legislature; but had also brought doubts concerning its practicability." ${ }^{9}$ This phrase of Resolution 6 was then passed unaltered 10 to 1 . The next two phrases of Resolution 6 (that the national legislature should have the power to legislate where the harmony of the U.S. may be interrupted by the exercise of individual state legislation and to negate all laws by the states contravening the articles of Union) were agreed to without debate or dissent (Farrand I, 53-54, 60-61). 
State paper money is first explicitly mentioned in the Convention on June 6th by Mason in the debate over whether the national legislature should be elected by the people or by the state legislatures with Mason being strongly in favor of election by the people. ${ }^{10}$ Mason argued that “...there was a better chance for proper elections by the people,...than by the State Legislatures. Paper money had been issued by the latter when the former were against it. Was it to be supposed that the State Legislatures then would not send to the National legislature patrons of such projects if the choice depended on them" (Farrand I, 134). By contrast, Pinckney favored election by the state legislatures rather than by the people. Pinckney "differed from gentlemen who thought that a choice by the people would be a better guard against bad measures, than by the Legislatures. A majority of the people in S. Carolina were notoriously for paper money as a legal tender; the Legislature had refused to make it a legal tender. The reason was that the latter had some sense of character..." (Farrand I, 137). ${ }^{11}$ Finally, in the continuation of this debate the next day Elbridge Gerry of Massachusetts, who also favored election by the state legislatures, insisted "that the commercial \& monied interests would be more secure in the hands of the State Legislatures, than of the people at large. The former have more sense of character, and will be restrained by that from injustice. The people are for paper money when the Legislatures are against it. In Massachusetts the County Conventions had declared a wish for a depreciating paper that would sink itself' (Farrand I, 154-155). This initial explicit introduction of state paper money into the Convention debates illustrates two argument-transformation themes in the rhetoric used at the Convention that would continue and escalate in intensity over the remainder of the Convention. The first argument-transformation theme is the equivocation or conflation of paper money 
emissions per se with legal tender powers. While Pinckney makes a clear distinction between state paper money as a legal tender and state paper money per se (suggesting that it is the former and not the latter that is bad), his statement will be (sans one other) the last time this distinction will be made at the Convention. Instead, as illustrated by Mason's and Gerry's comments, the subsequent comments on state monetary powers will undergo definition creep whereby emitting paper money and making paper money a binding legal tender will become synonymous. The rhetoric will then slide into just referencing the emission of paper money per se-forcing it to take on the entire mantle of what is evil about state monetary powers. The second argument-transformation theme is that in all subsequent comments on paper money there is a presumption that paper money per se is bad. The power to emit paper money became a rhetorical code phrase for evil.

On June 8th Pinckney and Madison proposed strengthening Resolution 6 of the Virginia Plan so that the national legislature would have the power to negate any state law the national legislature thought was improper, rather than just those contravening the articles of union. Though not directly mentioned, this change would give the national legislature the power unconditionally to stop all state emissions of paper money if it so wanted. In the ensuing debate, Gerry argued that he "could not see the extent of such a power, and was against every power that was not necessary. ... [But] He had no objection to authorize a negative to paper money and similar measures." Sherman wanted the cases enumerated where a negative could be applied. However, Wilson again stated, "A definition of the cases in which the Negative should be exercised, is impracticable." Others thought it would become a tool whereby the large states would tyrannize the small States. The Convention voted down the change 7 to 3 (Farrand I, 162-168). 
Gerry's comment in the above debate is the only time at the Convention prior to submitting the Convention's deliberations to the Committee of Detail (July 26th) that anyone suggested a specific monetary power that the national government should possess, namely the power to stop state emissions of paper money. Gerry's suggestion was also not taken up, commented on, or further debated before July 26th. His comment also illustrates the ease with which the definitional slide was made at the Convention from legal tender laws being the problem to state paper money per se being the problem.

On June 15 th Paterson presented what is traditionally referred to as the New Jersey Plan. Largely designed as a "small" state alternative to the "large" states' views on representation in the national government, it contained nothing specifically or indirectly that would bear on monetary powers, certainly nothing beyond that in the Virginia Plan (Farrand I, 241-280, III, 611-615). ${ }^{12}$ On June 18th Hamilton made his major speech that included his plan of government. Like the New Jersey Plan, the Hamilton Plan contained nothing directly or indirectly that would bear on monetary powers beyond that in the Virginia Plan. Hamilton did take the opportunity in his speech to join the chorus of rhetoricians using the emission of paper money per se as an illustration of an evil that had to be stopped. While lauding the British Constitution Hamilton said, "Their house of Lords is a most noble institution. .... They form a permanent barrier against every pernicious innovation,... No temporary Senate will have firmness enough to answer the purpose. The Senate of Maryland which seems to be so much appealed to, has not yet been sufficiently tried. Had the people been unanimous \& eager, in the late appeal to them on the subject of a paper emission they would have yielded to the torrent" (Farrand I, 282-311, III, 617-630). 
In a long speech on June 19th Madison argued that the New Jersey Plan would not “...prevent trespasses of the States on each other...[that] He considered the emissions of paper money as also aggressions. The States relatively to one another being each of them either Debtor or Creditor; the Creditor States must suffer unjustly from every emission by the debtor States. We have seen retaliating acts on this subject which threatened danger not to the harmony only, but the tranquility of the Union" (Farrand I, 317-318). ${ }^{13}$ Again the two argument-transformation themes appear in Madison's speech, namely, the problem created by binding legal tender laws - the "trespasses of the States on each other"-is redefined as being created by the emission of paper money per se and that this by itself is evil.

On July 16th the Convention revisited the clause of Resolution 6 of the amended Virginia Plan giving the national legislature the power "...to legislate in all cases to which the separate States are incompetent; or in which the harmony of the U.S. may be interrupted by the exercise of individual legislation..." The Convention again considered the vagueness of this power and whether it should be explicitly enumerated. Pierce Butler of South Carolina called for “.... some explanation of the extent of this power; particularly of the word incompetent. The vagueness of the term rendered it impossible for any precise judgment to be formed." Nathaniel Gorham of Massachusetts argued, "We are now establishing general principles, to be extended hereafter into details which will be precise \& explicit” (Farrand II, 17).

On July 17th the Convention again took up this clause in Resolution 6. This time it was Sherman who "observed that it would be difficult to draw the line between the powers of the General Legislatures, and those to be left to the States..." He proposed that 
the clause be amended to rule out national legislation that would "...interfere with the Government of the individual States in any matters of internal police which respect the Government of such States only, and wherein the General welfare of the United States is not concerned." Gouverneur Morris opposed this wording. He argued that "The internal police, as it would be called \& understood by the States ought to be infringed in many cases, as in the case of paper money \& other tricks by which Citizens of other States may be affected" (Farrand II, 25-26). Morris' rhetoric here has again muddled the lines between state paper money emissions per se and the power to declare them a legal tender, making the emission of paper money per se bear the entire burden of the problems caused by legal tender laws - the "tricks by which Citizens of other States may be affected."

Sherman's proposal was voted down, 8 to 2, and the original clause of Resolution 6, with some slight rewording, was passed 6 to 4 (Farrand II, 25-26). The debate over this clause up to this point is interesting for monetary powers. The strict construction of the clause would appear to give the national legislature no power to stop state emissions of paper money per se, but would appear only to give the national legislature the power to stop states from declaring said money a legal tender in trans-state or national transactions. However, Morris' statement above would appear to construe the clause more broadly, namely to include national prohibition of even a purely inside state paper money. Morris' statement seems to be claiming that anything whatsoever that will possibly affect a citizen of another state falls under the power of national prohibition in Resolution 6 regarding the "harmony of the United States."

Yet, later that same day (July 17th), Morris strongly opposed giving the national legislature the power to veto the "...laws passed by the several States..." (Farrand II, 27- 
28). This action contradicts the seemingly broad-power interpretation of his prior statement that he used when rejecting Sherman's motion. Considering all of Morris' statements together would appear to yield one consistent and narrow concern, namely getting the power to prevent state emission of paper money per se. In a letter to Timothy Pickering, December 22, 1814, Morris more or less admitted to this, saying that he had "little recollection" of the details of the Convention, but that "Propositions to countenance the issue of paper money, and the consequent violation of contracts, must have met with all the opposition I could make" (Farrand III, 419-420). Even years after the Convention, Morris continued to muddle the lines between paper money per se and legal tender laws. The "consequent violation of contract" would only occur if paper money were made a legal tender - again illustrating the slide of logic and definition creep intended to make the emission of paper money per se bear the entire burden of the problems cause by legal tender laws.

On July 17th the Convention also revisited the clause of Resolution 6 of the amended Virginia Plan giving the national legislature the power "To negative all laws passed by the several States contravening in the opinion of the National Legislature the articles of Union, or any treaties subsisting under the authority of ye Union." This clause, agreed to on May 31st without debate or dissent, now excited significant opposition. It was deleted by a vote of 7 to 3 (Farrand II, 27-28). Removal of this power would make it more difficult for the national government using the power in the prior clause in Resolution 6 (considered immediately above) to directly stop a state from issuing a legal tender paper money. 
On July 21 st, while debating whether the national judiciary along with the executive should have the power to revise or veto laws passed by the national legislature, Morris continued the drumbeat of the evils of legislative emissions of paper money per se. He said, "Emissions of paper money, largesses to the people-a remission of debts and similar measures, will at sometimes be popular, and will be pushed for that reason.... The press is indeed a great means of diminishing the evil, yet it is found to be unable to prevent it altogether" (Farrand II, 76). Morris' rhetoric here lumps paper money emissions per se with "largesses to the public" and "a remission of debts." But this would only typically be the case for paper money under a legal tender law and not for paper money per se (Holton 2004).

On July 26th the Convention's deliberations were submitted to a Committee of Detail to craft a draft constitution. Up to this point no explicit or direct proposals regarding monetary powers had been made. At best, what remained of Resolution 6 of the Virginia Plan potentially gave the national government the power to determine what monies could be legal tender for cross-state trade and in transactions with the national government, but as strictly constructed it probably could not be construed as giving the national government power to prohibit state emissions of a non-legal-tender inside paper money. However, Convention rhetoric on paper money, such as that by Gerry, Mason, Madison, Hamilton, and Morris had continuously conflated paper money with legal lender laws thus forcing the emission of paper money per se to bear the entire burden of the problems caused by legal tender laws. This rhetoric set the stage for the Committee of Detail to leap for the first time at the Convention to incorporating explicit clauses into the Constitution dealing with paper money emission per se. Convention rhetoric, however, 
may not have been enough to achieve this leap. Whether by conspiratorial craft or lucky

accident, a timely demonstration of the "evils" of state paper money was on display in

Philadelphia for the delegates to see.

\section{Paper Money Riot Interlude?}

A riot over Pennsylvania State paper money broke out in Philadelphia in mid-

July. The Pennsylvania Herald and General Advertiser described two incidents - the first

on July 14th:

A correspondent observes that the speculations of a few artful people have been frequently found extremely detrimental to the public; and no class is too low; that it cannot by a bold combination, accomplishith its object. The hucksters lately came to a resolution not to receive the copper-currency at less than 24 pieces for a shilling; but this depreciation was not publicly divulged til they had passed all their stock of half-pence at the former value. There are others who derive a livelihood from the exchange between the current mediums, that without any regard to the relative value, keep it in constant fluctuation, and, from day to day, pronounce upon the rate at which paper-money shall be taken for specie. The first instance is a reproach to the policy and morals of the state, for government should never leave it in the power of one part of the citizens to take advantage of the innocent ignorance of another; and the second instance is a reproach to the folly and weakness of those people, who will passively adopt the suggestions of interested men, instead of exercising their own judgment to show, that the security of the paper money is of an improving rather than a decaying nature.

And the second on July 21 st:

A correspondent remarks that the panic which prevailed on Saturday last [July 14th], respecting the paper-money of this state has not been more distressing to the poor, than astonishing to the intelligent part of the community. Many causes have been assigned for the sudden event, some grounded on mercantile negotiations, that never existed, and others drawn from mistaken or perverted interpretation of an expression which lately dropt from an eminent law character-but not one can stand a rational investigation.

Convention delegates were apparently aware of the goings-on and took away a darker view of the event than that painted in the newspaper. For example, Madison 
related the events to Thomas Jefferson, who was in Paris, in a letter dated July 18, 1787 (Smith 1995, I, 484):

The paper money here ceased to circulate very suddenly a few days ago. ... The entire stagnation is said to have proceeded from a combination of a few people with whom the Country people deal on market days against receiving it. The consequence was that it was refused in the market, and great distress brought on the poorer Citizens. Some of the latter began in turn to form combinations of a more serious nature in order to take revenge on the supposed authors of the stagnation. The timely interposition of some influential characters prevented a riot, and prevailed on the persons who were opposed to the paper, to publish their willingness to receive it. This has stifled the popular rage, and got the paper into circulation again. ... Nothing but evil springs from this imaginary money whenever it is tried, and yet the appetite for it, when it has not been tried, continues to be felt.

An interesting question for further research is whether these troubles were engineered by Morris' "monied interest" and/or the Bank of North America to help pave the way for an outright constitutional ban on paper money. Allan Nevins (522) concluded that the bank was involved, "In July of 1787, by concerted action, the banks and markets of Philadelphia ceased to accept them [Pennsylvania State paper money]." The timing of the stoppage by itself is suspicious. This event took place soon after Morris, a chief operating officer of the Bank of North America, returned to the Convention from New York where he had been since the end of May. It also occurred right before the Convention decided to revisit Resolution 6 of the Virginia Plan, and right before Morris began his drumbeat on the evils of paper money in his speeches from July 17th through July 21 st. And it occurred just before the Convention's deliberations were turned over to the Committee of Detail on which Wilson, a member of the board of the Bank of North America, was a key member. Otherwise, Pennsylvania State paper money had remained relatively stable over the long run as measured by its relatively constant (stationary with no trend) exchange rate to pounds sterling from 1784 through 1790 (Bezanson 1936, 346; 
Grubb 2003, 1786; 2005a). Finding a combination of speculators with enough control over specie exchange in Philadelphia to accomplish a stoppage of paper money exchange that didn't somehow involve the Bank of North America would be difficult. In any event, whether by conspiratorial craft or lucky accident, this overlooked episode may have been an important contributor to the radical transformation in constitutional monetary powers about to be undertaken at the Convention.

\section{The Committee of Detail-July 27 to Aug. 6: The Initial Restructuring of Monetary Powers}

On July 26th the Convention referred the Virginia Plan as amended by the Convention to that point, as well as the New Jersey Plan and the non-debated Pinckney Plan, to a Committee of Detail to craft a draft constitution. This Committee consisted of Oliver Ellsworth of Connecticut, Gorham, Randolph, Rutledge, and Wilson (Farrand II, $85,97-98,128-137)$. Five working drafts attributed to the Committee have survivedfour written by Wilson, with the last containing emendations by Rutledge, and one written by Randolph with emendations by Rutledge. Working backwards from the final product reported to the Convention on August 6th, Wilson's last working draft (with emendations by Rutledge) appears to be the principle penultimate draft of the Committee (Farrand II, 163-175, 177-189; Meigs 316-324). Where Randolph's draft fits within the first three Wilson drafts is hard to say; they overlap in some ways but not in others (Farrand II, 137-163; Meigs 316-324). Randolph's draft, unaltered by Rutledge, and the first two Wilson drafts say nothing about the power to emit paper money or about determining what monies may be made a legal tender either by the national government or by the state governments. 
Wilson's third draft includes for the first time in the constitution-creation process an explicit clause enumerating a monetary power, namely a restriction on legal tender"The Legislature of U.S. shall have the exclusive Power...of determining in what Specie of Money the public Treasury shall be supplied" (Farrand II, 158-159). Nothing else, however, is said prescriptively or proscriptively in this draft about the power to emit paper money or about determining what monies may be a legal tender within state jurisdictions. This power as explicitly enumerated here by Wilson was not mentioned in the records of the Convention. But as argued above, it seems to be one of the powers within the scope of the amended Resolution 6 of the Virginia Plan. While not appearing in the Pinckney Plan that was given to the Committee of Detail, the wording of Wilson's monetary power clause closely follows the wording in Pinckney's speech to the Convention on May 29th — as published after the Convention (Farrand III, 118).

At this juncture, the structure of the constitutional monetary powers being crafted were the closest to replicating the colonial monetary system as they ever would be. In Wilson's third draft constitution both the national government and the state governments still retained the power to emit paper money. The national government had been given an independent power to directly tax, thus allowing it to credibly commit to redeeming its paper money, a power which it had not had under the Articles of Confederation, thus solving the key structural problem underlying the collapse of the Continental dollar. The national government also had the power to determine what could be legal tender for national government transactions. This almost replicated the British legal tender restrictions placed on the colonies. 
From this point, the Convention embarked on a path leading to a radical departure from the colonial system. In Wilson's last (fourth) working draft he dropped the legal tender restriction clause from his third draft and substituted in its place the clause, with Rutledge reordering the words slightly, "No State shall...without the Consent of the Legislature of the United States emit Bills of Credit." In addition, the national legislature's power to emit bills of credit, part of the old powers carried over from the Articles of Confederation, was now made an explicitly enumerated power given to the national legislature (Farrand II, 168-169). No statement about legal tender powers at any level of government was included in Wilson's last draft. Perhaps Wilson reasoned that if Congress had the power to ban states from emitting paper money that would solve the problem of determining what monies could be a legal tender for national government transactions - the former power encompassing the latter. But this change was also a radical step in that it gave Congress, for the first time, the power to ban states from issuing even a non-legal-tender inside paper money. This change would appear to be going beyond the principles laid out so far by the Convention regarding national powers not being allowed to interfere in matters purely internal to a state.

Besides emendating Wilson's last working draft, Rutledge also added comments to Randolph's draft. In a margin note to Randolph's enumerated powers given to the national government "To regulate coining" Rutledge wrote "no State to be perd. in future to emit Paper Bills of Credit witht. The App: of the Natl. Legisle nor to make any Thing but Specie a Tender in paymt of debts" (Farrand II, 144). Given that the second half of this clause does not appear in Wilson's last working draft which Rutledge had also emendated but does appear in the Committee's final draft submitted to the Convention, it 
seems likely that Rutledge added this note to Randolph's draft near the very end of the Committee's deliberations. As argued above, the true monetary problem was the legal tender issue. Perhaps Rutledge reasoned if Congress only had Wilson's power to ban state paper money, then that would not necessarily solve the legal tender problem. States might declare something else to be a legal tender, such as bonds, state banknotes, tobacco contracts, or land deeds. If trans-jurisdictional (outside) money was always to be specie, then states had to be prevented from making "any Thing but Specie" a legal tender.

The draft constitution submitted by the Committee to the Convention on August 6th gave the national legislature the explicitly enumerated power to "...emit bills on credit...", and an explicitly enumerated power over state paper money and legal tender laws, i.e. stating that "No State, without the consent of the Legislature of the United States, shall emit bills of credit, or make any thing but specie a tender in payment of debts...” (Farrand III, 182, 187; Meigs 134-135, 180-182, 311). By explicitly enumerating individual monetary powers, the Committee was forcing the Convention to deal up or down with these powers separately, as opposed to dealing with monetary powers as implied by other granted powers. What is interesting is that it would be Wilson himself, along with his Bank of North America protégé Morris, who would lead the attack on these narrowly enumerated monetary clauses, the clauses that Wilson was the first to draft out, in order to narrow and radicalize their scope even further. 


\section{The End Game-Aug. 6 to 28: The Absolute Constitutional Proscription of}

\section{Monetary Powers}

\section{A. The Absolute Prohibition on Paper Money Issued by the National Government}

From the initial Virginia Plan presented at the beginning of the Convention through all the Convention's deliberations given to the Committee of Detail, the national legislature was designed to have all the rights and powers it possessed under the Articles of Confederation plus some new and enlarged powers. The Committee of Detail drafted a list of these new and enlarged powers. In Wilson's last draft, but not before, this list included the power to "emit bills on the credit of the United States" (Farrand I, 21; II, 131, 142-144, 158-159, 167-169, 181-183). Under the Articles of Confederation, Congress had exercised the power to emit bills of credit. Why the Committee of Detail took it upon itself in its last draft, and for the first time in the constitution-revision process, to put this one "old" power on the list of specifically enumerated "new and enlarged" powers of the federal government is unclear. One outcome of doing this became clear within a few days. By isolating this one "old" power from the other exiting "old" powers, it became easier to attack and expunge.

With Congress being granted the new power to directly tax, the structural problem under the Articles of Confederation that distinguished the well-working colonial monetary system from the Continental dollar disaster had been removed. Under the draft of the new constitution offered by the Committee of Detail, paper money issued by the federal government, if not made a legal tender, should have worked as well as paper money had in the late colonial period. However, within ten days of receiving this draft 
constitution, the Convention decided that under absolutely no circumstances should the federal government be allowed to issue paper money.

Gouverneur Morris led the attack on this power. The first two attacks were indirect, with the first presented on August 15th during the debate over how easily an executive veto of Congressional legislation could be overridden. Morris argued that Congress should not have an ability to override an executive veto and, if that was not agreeable, requiring a $3 / 4$ vote rather than the proposed $2 / 3$ vote of Congress to override an executive veto would be preferable. Madison recorded Morris as having

dwelt on the importance of public Credit, and the difficulty of supporting it without some strong barrier against the instability of legislative Assemblies. ... The legislature will contrive to soften down the President. He recited the history of paper emissions, and the perseverance of the legislative assemblies in repeating them, with all the distressing effects of such measures before their eyes. Were the National legislature formed, and a war was now to break out, this ruinous expedient would be again resorted to, if not guarded against (Farrand II, 299).

The Convention voted for a 3/4 rule (Farrand II, 301).

What is interesting about Morris' argument here is that he explicitly links the ruinous problems of paper money to "war." "14 Was he admitting that paper money issued by the federal government under the new constitution would not be a problem during peacetime? The Convention delegates were likely aware of the "ruinous" effects of Congress' wartime issue of the paper Continental dollar. The exigencies of war would typically require issuing more bills of credit than what could be credibly redeemed in the near future through taxation. Wartime inflation and price controls would be the likely result (Rockoff). Whether wartime inflation could have been avoided, regardless of the monetary powers of the federal government, was not considered. Given that the debate was not about wartime versus peacetime powers, Morris may have been trying to link the 
disastrous wartime inflation of the Continental dollar already firmly planted in the minds of the delegates with the general "evils" of paper money per se.

The second indirect attack came early on August 16th when the Convention took up debating whether the federal government should have the power to tax exports. Among his arguments in favor of taxing exports, Morris stated, "Taxes on exports are a necessary source of revenue. For a long time the people of America will not have money to pay direct taxes. Seize and sell their effects and you push them into Revolts—." The Convention, however, for other political reasons voted eventually not to allow the federal government to tax exports (Farrand II, 307, 374, 657).

Morris' comment says a lot about what he anticipated would be the course of events under the monetary powers he wanted in the Constitution. Why would the "people of America...not have money to pay direct taxes" to the federal government? If the federal government issued an inside paper money, it would have to accept that paper money in payment of its taxes. Having issued said inside money the people of America would have little problem getting that money to pay federal taxes because, unlike outside money (specie), it would seldom exit the country. If, however, the federal government was prohibited from issuing an inside paper money, then taxes would have to be paid in outside money, namely specie. For the most part, specie flowed into the economy from the trade surpluses with the Caribbean and flowed out through the trade deficits with Europe. Short-run trade imbalances always occurred. While periods of specie surplus created little problem for paying federal taxes, periods of specie scarcity would be consistent with what Morris was referring to when he talked about people not having "money to pay direct taxes." And Morris seemed to be expecting that periodic specie 
scarcity would be a prevalent condition in the near future (Holton 2004, 2005b). Because exports are more likely to be purchased with specie, taxing exports would give the federal government direct access to specie as tax payments.

Morris' comment also comes close to admitting what the true problem was regarding the late 1786 and early 1787 rebellion in Massachusetts, called Shay's Rebellion, that so affected the delegates at the Convention — the likely reference to "Revolts" in the above quote. If inside paper money is eliminated and the general public is required to pay taxes in specie, as Massachusetts did after the Revolution, and if shortrun shifts in external trade cause a period of specie scarcity, then some people will be tax delinquents and forced into bankruptcy. The government will have to confiscate and sell the tax delinquents' property for tax arrears. Such distressed property sales, when specie is scarce, leads to substantially lower-than-average prices for the tax delinquents' property. Those with wealth scoop up this property as fire-sale bargains. Given that those who got the fire-sale bargains may have also been or were suspected of being involved in engineering the passage of such money-tax policies in the first place, a sense of injustice and hence revolt was the outcome. This was the essence of Shay's Rebellion, as well as the Whiskey Rebellion in western Pennsylvania in 1796. Stopping something like this also lay behind the Rhode Island emission of paper money in 1786 (Bishop; Bouton; Grubb 2003, 1789-1790; Holton 2004). Federalist rhetoric paints these episodes as excesses of democracy where the populous rage for an inflationary paper money was led by debtors out to cheat their creditors. By contrast, these episodes may really have been examples of wealthy creditors out to use their power in government to alter the rules and confiscate more wealth from the poor. ${ }^{15}$ For Morris, the federal government's direct 
access to specie via taxing exports was one solution to the chain of events that might

likely accompany a prohibition on paper money emissions.

Having set the stage and gauged the opinions of Convention delegates, late on August 16th Morris made his move to absolutely ban federally-issued paper moneymoving to strike out the words "and emit bills on the credit of the United States" from the enumerated powers granted the national legislature. He reasoned that "If the United States had credit such bills would be unnecessary: If they had not unjust \& useless." The debate that followed is worth quoting at length:

Mr. Madison, will it not be sufficient to prohibit the making them a tender? This will remove the temptation to emit them with unjust views. And promissory notes in that shape may in some emergencies be best.

Mr. Gouverneur Morris. Striking out the words will leave room still for notes of a responsible minister which will do all the good without the mischief. The Monied interest will oppose the plan of Government, if paper emissions be not prohibited.

Mr. Gorham was for striking out, without inserting any prohibition. If the words stand they may suggest and lead to the measure.

Col. Mason had doubts on the subject. Congress he thought would not have the power unless it were expressed. Though he had a mortal hatred to paper money, yet as he could not foresee all emergencies, he was unwilling to tie the hands of the Legislature. He observed that the late war could not have been carried on, had such a prohibition existed.

M. Gorham-The power as far as it will be necessary or safe, is involved in that of borrowing.

Mr. Mercer was a friend to paper money, though in the present state \& temper of America, he should neither propose nor approve of such a measure. He was consequently opposed to a prohibition of it altogether. It will stamp suspicion on the Government to deny it a discretion on this point. It was impolitic also to excite the opposition of all those who were friends to paper money. The people of property would be sure to be on the side of the plan, and it was impolitic to purchase their further attachment with the loss of the opposite class of Citizens

Mr. Ellsworth thought this a favorable moment to shut and bar the door against paper money. The mischiefs of the various experiments which had been made, were now fresh in the public mind and had excited the disgust of all the respectable part of America. By withholding the power from the new Government more friends of influence would be gained to it than by almost any thing elsePaper money can in no case be necessary - Give the Government credit, and other resources will offer-The power may do harm, never good. 
Mr. Randolph, notwithstanding his antipathy to paper money, could not agree to strike out the words, as he could not foresee all the occasions that might arise.

Mr. Wilson. It will have a most salutary influence on the credit of the United States to remove the possibility of paper. This expedient can never succeed whilst its mischiefs are remembered. And as long as it can be resorted to, it will be a bar to other resources.

Mr. Butler. remarked that paper was a legal tender in no Country in Europe. He was urgent for disarming the Government of such a power.

Mr. Mason was still averse to tying the hands of the Legislature altogether. If there was no example in Europe as just remarked it might be observed on the other side, that there was none in which the Government was restrained on this head.

Mr. Read, thought the words, if not struck out, would be as alarming as the mark of the Beast in Revelations.

Mr. Langdon had rather reject the whole plan than retain the three words "and emit bills."

[The motion to striking out "and emit bills" was passed 9 to 2.] ${ }^{16}$ (Farrand II, 308$310)$.

There are several important aspects to this debate. First, the logic of the rhetoric used above indicates that the founding fathers were operating under the assumption that unless a power was explicitly given to the national government in the Constitution (or directly implied by a power explicitly granted) that that power was denied to the national government. By voting to strike out the words "and emit bills of credit" from the list of powers to be given Congress, they considered themselves as voting to prohibit paper emission by the national government - else their vote makes no sense. An explicit vote to remove a power would trump any "implied" power argument for the national government retaining that power under the auspices of some other explicitly granted power-else explicitly removing that power from the list of powers granted makes no sense (assuming that the founding fathers were not deliberately writing a deceitful Constitution-ratifying one meaning while intending to execute another). 
Second, for only the second (and last) time at the Convention the distinction was raised between legal tender laws and the emission of paper money per se. And when Madison raised this distinction —-indicating that it was legal tender laws that caused all the problems-Morris' response was blunt and absolute, "The Monied interest will oppose the plan of Government, if paper emission be not prohibited." This absolute prohibition with no qualifying considerations, and the (rather grandstanding) willingness of Morris and his "monied interest" to risk losing the whole Constitution if an absolute prohibition was not agreed to, was also echoed by several other delegates in the quote above. ${ }^{17}$ In addition, as if in answer to Madison, the game of conflating legal tender laws with the emission of paper money per se was reasserted by all the other delegates speaking on this matter. This absolute, risk all, no-compromise position taken by the "monied interest" on absolutely banning federally-issued paper money logically implies the same position with regard to state-issued paper money, which will be seen to be the case below.

Third, this debate reveals that the delegates seemed to know that the recent problems with paper money were not due to paper money per se, but were largely due to the problems of wartime finance and its aftermath (post-war depression). For example, Mercer refers to the "present state \& temper of America" regarding paper money. Wilson refers to the memory of paper money's "mischiefs." Ellsworth refers to this time being "a favorable moment to shut and bar the door against paper money. The mischiefs of the various experiments which had been made, were fresh in the public mind...” They seemed willing to try the ignorance of the public and muddle the distinction between peacetime and wartime financial performance in order to justify an absolute ban on paper 
money emissions. If the public only remembered that the Continental dollar hyperinflated, and did not delve into the underlying causes of it, then they might easily blame it on the emission of paper money per se. That a paper money expedient could be the best choice from among the set of necessary financing evils during a war was noted but not seriously considered. Madison's reference to some “emergencies" and Randolph's to not being able to "foresee all occasions," when paper money might be useful, would seem to refer to wartime financing, and Mason explicitly says that "the late war could not have been carried on" without paper money. The peacetime versus wartime financial distinction was trampled under in the drive to absolutely ban government-issued paper money.

Fourth, Morris says something very cryptic and telling about what alternatives might be available. In response to Madison's legal tender question, Morris initially says, "striking out the words leave room still for notes of a responsible minister which will do all the good without the mischief." Who did Morris mean by "responsible minister"? It cannot be an official arm of the national government as Morris finishes his statement with "The Monied interest will oppose the plan of Government, if paper emissions be not prohibited." And no government "minister" in the executive branch, such as the future Secretary of the Treasury, would have an independent power to tax and so control paper money backing or have the power to control specie deposits in such a way as to function as Morris' "responsible minister" for issuing paper money. Who else is left? There is perhaps only one candidate, Morris' Bank of North America. ${ }^{18}$

Since 1782 the Bank of North America had been trying to get its banknotes to circulate as a national paper currency (Ferguson 1983, 402; Grubb 2003, 2004a; Lewis; 
Wilson). Wilson, a member of the board of the bank, had argued in 1785 that the “...advantage...[of] the bank of North America is the establishment of an undepreciating paper currency through[out] the United States" (Adams 146). Apparently, Morris and Wilson are not against all paper money, only against tax-backed government-issued paper money. Banknotes that were fractionally backed in specie were acceptable. In other words, Morris wanted governments at all levels to surrender paper money issuing power to private banks, with the only quasi-national bank at the time being his Bank of North America. Why did Morris use the cryptic phrase "responsible minister" and not just come right out and say "Bank of North America"? It is likely, as will be shown below, that Morris did not say "bank" because the mere mention of the word, even among the Convention delegates, was so controversial that it was likely to kill the new Constitution. $^{19}$

\section{B. The Absolute Prohibition on Paper Money Issued by State Governments}

Having secured an absolute ban on federally issued paper money, the move to absolutely prohibit state issued paper money was probably a foregone conclusion. On August 28th the Convention got to that part of the draft constitution. ${ }^{20}$ Wilson and Sherman moved to cut the phrase "without the consent of the Legislature of the United States" from the clause "No State, without the consent of the Legislature of the United States, shall emit bills of credit, or make any thing but specie a tender in payment of debts..." This change, "making these prohibitions absolute," elevated state paper money to being on a par with higher-order political matters such as prohibiting states from entering foreign alliances (Farrand II, 187, 657). 
Having achieved the ban on federal bills of credit with the argument that "The Monied interest will oppose the plan of Government, if paper emissions be not prohibited," the ensuing debate was short:

Mr. Gorham thought the purpose would be as well secured by the provision... which makes the consent of the General Legislature necessary, and that in that mode, no opposition would be excited; whereas an absolute prohibition of paper money would rouse the most desperate opposition from its partisans-

Mr. Sherman thought this a favorable crisis for crushing paper money. If the consent of the Legislature could authorize emissions of it, the friends of paper money would make every exertion to get into the Legislature in order to license it.

The question was divided into whether to have an absolute prohibition on states emitting bills of credit, which passed 8 to 2 , and whether to make the legal tender clause an absolute prohibition, which passed 11 to 0 (Farrand II, 435, 439). The separate votes on the two clauses indicate that the founding fathers could have potentially decided only to absolutely ban legal tender provisions but not state paper money emissions per seindicating that despite the rhetoric that frequently conflated these two issues the founding fathers recognized that legal tender laws and paper money emissions per se were in fact not the same issue. ${ }^{21}$

Sherman's statement about it being a "favorable crisis" for crushing paper money suggests that paper money per se was not the problem, and that the public's confusion of wartime finance and post-war depression monetary problems with peacetime or normal monetary performance could be used to win an absolute paper money ban. Gorham's statement, as well as John Francis Mercer's statement in the prior quote, also suggests that the anti-paper money faction was willing to risk alienating much of the public and so jeopardize ratification in order to get an absolute ban on paper money at all levels of government. ${ }^{22}$ 
Finally, on the same day a short debate took place that reveals what was not the motive for banning state paper money. Rufus King of Massachusetts, "moved to add, ... a prohibition on the States to interfere in private contracts" to the list of powers to be prohibited to the states. Morris responded that, "This would be going too far. ... and within the State itself a majority must rule, whatever may be the mischief done among themselves." Sherman then asked, "Why then prohibit [State] bills of credit?" To which no answer was recorded (Farrand II, 439-440). For Morris, the problem with paper money apparently was not that it could be used to redistribute income from one group to another by effectively altering values within private contracts via legal tender laws and/or unanticipated inflationary issues of paper money. Morris recognized that there were myriad ways of redistributing income via state laws that were probably easier to institute regarding the targeting of benefits than the rather clumsy method of issuing a depreciating state currency (Nettels 85-86). Morris apparently did not care about intrastate political machinations leading to income redistribution schemes-rejecting one of the common arguments the historical literature has ascribed to the Convention (and him) for why state paper money was banned.

VI. National Banking as a Substitute Monetary Power?-Aug. 28 to Sept. 14

The British extended the Bubble Act to the colonies in 1741. This Act did not allow corporations to form that had over six partner/investors, which in turn effectively stopped commercial banks from developing in the colonies (Perkins 41; Priest). With independence, colony/states were free to incorporate banks, which they began to do in 1781 when Pennsylvania chartered the Bank of North America, and in 1784 when New York and Massachusetts chartered the Bank of New York and the Bank of Massachusetts, 
respectively. Efforts to charter banks were underway in other states between 1784 and 1787, such as in Maryland where the state's Senate had passed a bank charter bill that was being blocked by that state's House of Delegates. These banks took in deposits in specie and issued banknotes as claims against said deposits and as loans. Depositors could also issue checks as claims on their specie deposits. These banks were basically engaged in modern, though unregulated, fractional-reserve practices with specie serving as reserves. They issued more banknotes, loans, and claims on their specie deposits than they had specie on reserve. While not a legal tender, these banknotes circulated as a geographically localized currency because they could be redeemed in specie at the issuing bank at face value, except during liquidity crises, but at variable marketdetermined discounts off the face value farther away from the issuing bank. Banknotes competed with each other for usage as an inside paper money and with state bills of credit. Banks and bank charters were a contentious and controversial issue in many state legislatures (Behrens 79-87; Bryan 17-19; Freeman 575-612; Gras; Grubb 2003, 2005a; Lewis; Nettels 75-81; Webster; Wilson).

\section{A. Who Shall Have the Power to Charter Banks?}

At the Convention, the delegates did not address the states' power of incorporation, either in general or with specific reference to banking. Apparently such state powers were acceptable to the founding fathers and they were to be left intact by the new Constitution. Several delegates were closely involved with state chartered banks, either as stockholders, board members, directors, legal advisors, or sponsors of banking bills, including Hamilton, Gerry, King, McHenry, John Langdon of New Hampshire, Abraham Baldwin of Georgia, and the entire Pennsylvania delegation of Wilson, 
Franklin, Thomas Mifflin, George Clymer, Jared Ingersoll, Thomas Fitzsimons, Robert Morris, and Gouverneur Morris (Grubb 2003, 2005a; McDonald 89). Perhaps then it is not surprising that the state power to charter banks was left untouched by the Convention. Under the Articles of Confederation it was doubtful whether Congress had the power to charter a national bank. For example, in 1780 Hamilton suggested that a national "Convention should assemble" to remedy the Articles of Confederation by granting Congress the power of "establishing banks...." (Freedman 76-77). In the 17851787 controversy in the Pennsylvania State Legislature over that state's charter of the Bank of North America, which Congress had also chartered and intended to be its national bank, the actions of both the pro- and anti-bank parties indicated that both sides had little faith in the validity of a charter from Congress. Both sides thought a state charter was necessary (Lewis; Rappaport; Webster; Wilson). If a national bank chartered by the federal government were to be allowed, it would have to fall under one of the new and enlarged powers specifically enumerated in the new Constitution.

Whether the national government should be given the power to charter a national bank was taken up in a roundabout way on September 14th when the Convention addressed the general versus specific powers of incorporation to be granted the national government. With regard to the power of incorporation, the draft constitution up to that point gave the national government only the specific enumerated power to establish post offices and post roads. Franklin moved that the national government also have the power to cut canals. The debate expanded from there and the exchange between the delegates is worth quoting at length (from Madison's notes):

Mr. Madison suggested an enlargement of the motion into a power "to grant charters of incorporation where the interest of the U.S. might require \& the 
legislative provisions of individual States may be incompetent." His primary object was however to secure an easy communication between States which the free intercourse now to be opened, seemed to call for-The political obstacles being removed, a removal of the natural ones as far as possible ought to follow. Mr. Randolph 2ded. the proposition.

Mr King thought the power unnecessary. welfare.

Mr Wilson. It is necessary to prevent $a$ State from obstructing the general

Mr King — The States will be prejudiced and divided into parties by it - In Philadelphia \& New York, It will be referred to the establishment of a Bank, which has been a subject of contention in those Cities. In other places it will be referred to mercantile monopolies.

Mr. Wilson mentioned the importance of facilitating by canals, the communication with the Western Settlements-As to Banks he did not think with Mr. King that the power in that point of view would excite the prejudices \& parties apprehended. As to mercantile monopolies they are already included in the power to regulate trade.

Col: Mason was for limiting the power to the single case of Canals. He was afraid of monopolies of every sort, which he did not think were by any means already implied by the Constitution as supposed by Mr. Wilson.

The motion being so modified as to admit a distinct question specifying \& limited to the case of canals. [The motion failed 8 to 3.]

The other part fell of course, as including the power rejected (Farrand II, 615-616).

McHenry's notes support Madison's notes on this issue. He wrote, "Moved by Dr.

Franklin seconded by Mr. Willson, to empower Congress to open and establish canals.

This being objected to - moved by Virginia To empower Congress to grant charters of incorporation in cases where the U.S. may require them and where the objects of them cannot be obtained by a State. Negatived" (Farrand II, 620).

Both Madison's and McHenry's notes of the Convention for that day are corroborated by an incident recorded by Jefferson some years later. Jefferson wrote in his personal notes on March 11, 1798:

[Abraham] Baldwin [Convention delegate from Georgia] mentions at table the following fact. When the bank bill [First Bank of the U.S.] was under discussion in the House of Representatives [1791], Judge [James] Wilson came in, and was standing by Baldwin. Baldwin reminded him of the following fact passed in the grand [1787] convention. Among the enumerated powers given Congress, was 
one to erect corporations. It was, on debate, stuck out. Several particular powers were then proposed. Among others, Robert Morris proposed to give Congress a power to establish a national bank. Gouverneur Morris opposed it, observing that it was extremely doubtful whether the constitution they were framing could ever be passed at all by the people of America; that to give it its best chance, however, they should make it as palatable as possible, and put nothing into it not very essential, which might raise up enemies; that his colleague (Robert Morris) well knew that 'a bank' was, in their State (Pennsylvania) the very watch-word of party; that a bank had been the great bone of contention between the two parties of the State...that therefore, to insert this power, would instantly enlist against the whole instrument, the whole of the anti-banking party in Pennsylvania.

Whereupon it was rejected, as was every other special power, except that of giving copyrights to authors, and patents to inventors; the general power of incorporating being whittled down to this shred. Wilson agreed to the fact (Farrand III, 375-376).

Apparently banks were more controversial than paper money, with the mere mention of them, even indirectly, threatening the likely ratification of the Constitution. Perhaps this is why on August 16th Gouverneur Morris used the term "responsible minister" rather than "Bank of North America" when referring to a paper-money substitute to federally issued bills of credit (Farrand II, 309).

\section{B. The Post-Convention Constitutional Controversy over Who Can Charter Banks}

It appears that the Convention intended not to give, and in a roundabout way voted against giving, the federal government the power of incorporation, including the particular power to charter banks. In 1791, however, Congress voted to charter a national bank - the First Bank of the U.S. - to serve as the federal government's bank. A sharp debate and on going controversy ensued over the constitutionality of this act (Holdsworth 17-19). How was this possible given the Convention debate quoted above?

The Constitution's construction was that any new or enlarged power that went beyond the Articles of Confederation that was not explicitly enumerated as granted to the

federal government was denied it. This construction explains the Constitution's brevity. ${ }^{23}$ 
Except for erecting post offices and post roads, the power of incorporation including the power to charter banks was not one of the new enumerated powers granted the federal government. However, the powers explicitly voted by the Convention not to be included among these enumerated powers, by construction, were not to be written into the Constitution — thus keeping the Constitution from becoming an overly long and unwieldy document.

This method of construction, however, opened an interpretive door that Hamilton and supporters of a national bank rushed through. When a particular power was not explicitly enumerated, Congress might still possess that power if that power was implied by other powers that were explicitly enumerated in the Constitution. Hamilton was the first to articulate this implied-powers doctrine, and it was in reference to the constitutionality of the First Bank of the U.S. (Rutland XIII, 370-404; Syrett VIII, 62134). This doctrine went on to become a well-known and much-studied doctrine of interpretation of constitutional law.

This doctrine is derived from the conclusion to Section 8 of Article 1 of the Constitution that enumerates the powers of Congress. It states that Congress has the power "To make all Laws which shall be necessary and proper for carrying into Execution the foregoing Powers, and all other Powers vested by this Constitution in the Government of the United States, or in any Department or Officer thereof." The rather plain language of this clause belies ascribing much genius to the creation of a "doctrine" of implied powers. Most anyone at the time could read, understand, and more-or-less agree on the broad meaning of this clause. For example, the Constitution did not give Congress the explicit power to create a mint, but it did give it the explicit power to coin 
money. Almost everyone seemed to agree that the power to coin money implied the power to create a mint in order to coin money. The first Congress' Congressional Mint Act was constitutionally uncontroversial. By contrast, Congress' Constitutional power to coin money was not construed to imply the power to go into the goldsmith business or charter mining companies. ${ }^{24}$

Hamilton's use of the implied-powers doctrine to assert that the First Bank of the U.S. was constitutional can be seen as a rhetorical smoke screen. Hamilton's foes could read the implied-powers clause in the Constitution as well as he could. Their constitutional objection to the First Bank of the U.S. was not over the application or interpretation of this clause. To repeat: It's not about implied powers. Implied powers were a necessary but not a sufficient condition. ${ }^{25}$

An explicit vote at the Convention to deny the federal government a particular power trumps any implied-powers argument for the federal government retaining such a power under the auspices of some other explicitly granted power. If this were not the case, then explicitly voting to remove said power from the list of granted powers makes no sense (assuming the founding fathers were not writing a deceitful Constitutionratifying one meaning while intending to execute another). If the Convention had explicitly voted not to give the federal government the power to charter a national bank, then that vote would trump any implied-power interpretation of the constitutionality of the First Bank of the U.S. Hamilton's own rhetorical position as well as that of Madison and Gerry (see below) is consistent with this understanding.

Hamilton's application of the implied-powers doctrine would be irrelevant if it were known that the Convention had debated and explicitly voted not to give the federal 
government the power to charter a bank. As such, the bank supporters had to argue that no such debate or explicit vote took place at the Convention. Because no records of what transpired at the Convention were yet published in 1791, such an argument might —and did—succeed. This was the real issue over the constitutionality of the bank.

The Convention had been closed to the public. The Convention's official Journal, which was not made public until 1819, was in President Washington's keeping (Farrand I, xi-xxi; II, 648). The Journal, however, recorded almost nothing on the day in question (September 14th) — only an 8 to 3 vote against "To grant letters of incorporation for Canals \&ca" (Farrand II, 610-611). The words "\&ca" seem to indicate something in addition to canals, but these words were not noted or discussed. ${ }^{26}$ Madison's notes were not public, and would not be published until 1840, after Madison's death. McHenry's notes, the only other notes taken that day, would not be published until even later (Farrand I, xv-xxi).

In 1791 when Congress proposed the bill to charter the First Bank of the U.S., Madison argued in Congress that the bill was unconstitutional "because he well recollected that a power to grant charters of incorporation had been proposed in the General Convention and rejected" (Farrand III, 362). Madison had proposed that power at the Convention and so was likely to have been attentive regarding the ensuing debate. Madison also had his Convention notes to consult. Whether Madison let anyone else see his notes is unclear. There is no indication by him or from anyone else that he did. Madison was "regarded by his fellow delegates to the Convention as a semiofficial reporter of their proceedings, for several of them took pains to see that he was supplied with copies of their speeches and motions" (Farrand I, xvi). Given that the 
Journal failed to record most of the debates, Convention delegates who did not remember the debates of a given day should have deferred to Madison's recollection based on his detailed semi-official notes. Some clearly did. Randolph, who was Attorney General in 1791, as well as Jefferson as Secretary of State, concurred with Madison's memory and/or accepted the authority of his recollection. For Madison, Randolph, and Jefferson there wasn't much to debate. Implied powers were not enough. The Convention had explicitly voted not to allow Congress that power, so the First Bank of the U.S. was unconstitutional. They recommended that President Washington veto the bill as unconstitutional (Farrand III, 362-363; Rutland XIII, 370-404).

President Washington was at the Convention on September 14th. Either he knew from his own memory what Madison knew, or he did not rightly remember that day's debates. The latter could well be likely. Washington never engaged in the debates at the Convention and so may have paid little attention to particular debates. Washington did possess the Convention's Journal, but this Journal recorded almost nothing on the topic at hand. But if Washington didn't remember the debates of that day himself, why did he not accept Madison's recollection as definitive since it was based on Madison's own semi-official notes? At the Convention, Washington mostly likely watched Madison take these notes every day. ${ }^{27}$ Perhaps Washington's sympathies were strongly tied to his fellow officer Hamilton. Perhaps Hamilton and Robert Morris—-head of the Bank of North America and at whose house Washington often dined during the Convention-had persuaded Washington that a national bank was necessary (Huston; Warren). Perhaps Washington was predisposed to favor any interpretative opening that would allow him not to veto the bill. 
With no public record showing that the Convention explicitly voted not to allow Congress the power of incorporation, the supporters of the bank could ignore Madison's statement. Instead, they could claim that no one at the Convention rightly remembered what happened and that no such debate or vote may have even taken place. Indeed, Gerry, who favored a national bank, was present at the Convention on September 14th, but in February of 1791 he disagreed with Madison's recollection of that day. He said, in direct reference to Madison's last quote above, “.... are we to depend on the memory of the gentleman [Madison] for a history of their debates, ... This would be improper, because the memories of different gentlemen would probably vary, ... with respect to those facts; ... no motion was made in that Convention, and therefore none could be rejected for establishing a National Bank; ...” (Farrand III, 362-363). This also indicates that it was unlikely that Madison showed his notes of the Convention to anybody else.

Hamilton made a similar statement later that month when he wrote a defense of the constitutionality of First Bank of the U.S. in order to give Washington a reason not to veto the bill,

Another argument...is, the rejection of a proposition by the Convention to empower Congress to make corporations, either generally, or for some special purpose.

What was the precise nature or extent of this proposition, or what the reasons for refusing it, is not ascertained by any authentic document, or even by accurate recollection. As far as any such document exists, it specifies only canals. ... It must be confessed, however, that very different accounts are given the import of the proposition, and of the motives for rejecting it. Some affirm that it was confined to the opening of canals and obstructions in rivers; others, that it embraced banks; and others, that it extended to the power of incorporating generally. Some, again, allege that it was disagreed to because it was thought improper to vest in Congress a power of erecting corporations. Others, because it was thought unnecessary to specify the power, and inexpedient to furnish an additional topic of objection to the Constitution. In this state of the matter, no inference whatever can be drawn from it (Farrand III, 363-364). 
Hamilton makes three interesting references in his argument. First he referred to no "authentic document" supporting Madison's recollection. The only "authentic document" that exists refers only to canals. Hamilton seems to be referring to, and had consulted, the Convention's Journal which was at that time in Washington's keeping. Hamilton did not consider any other notes from the Convention to be an "authentic document." Given that these other Convention notes had not yet been published or otherwise made available for others, Hamilton could plausibly deny that he was making an inaccurate assessment.

Second, Hamilton's rhetoric presumes that an explicit vote at the Convention to deny the federal government a particular power trumped any implied-powers argument. If a clear inference could be drawn from an authentic document that the Convention had voted to deny the federal government a given power, that sealed the fate of that power-it was absolutely denied to the federal government. If the Convention's Journal had recorded the debate as extensively as Madison had recorded it, then by Hamilton's own rhetorical structure the bank was most likely unconstitutional. More troubling is Hamilton's penultimate sentence quoted above. It seems to imply that the Constitution offered to the public for ratification may have been intentionally misleading regarding the monetary powers that he now intended to exercise.

Third, Hamilton asserts in reference to the debates at the Convention on September 14th that, “...the precise nature or extent of this position... [can] not [be] ascertained...by accurate recollection." Why did Hamilton not refer to his own recollection from that day? His statement suggests that he was not present that day. Madison records Hamilton as speaking at the Convention on September 12th and then 
next on September 17th, but not between those days. His absence on September 14th would also be consistent with the fact that if he were there it seems likely that he would have spoken since national banks had long been an issue of importance to him (Freeman 1040; Syrett II, 400-418). If Hamilton was there and remembered the debate as recorded by Madison, then he was willingly subverting the Constitution. If Hamilton either did not remember the debate or was not in attendance, why did he not accept Madison's recollection as definitive ${ }^{28}$ Hamilton knew that Madison had taken copious and semiofficial notes of the Convention. Hamilton had himself given Madison a copy of his own speech to the Convention so that Madison could accurately record it in his notes (Farrand I, xvi, 282-293; III, 617-630). ${ }^{29}$ Washington and Hamilton's unwillingness to defer to Madison's semi-official note-based recollection is consistent with a willingness on their part to subvert the Constitution over the bank issue. ${ }^{30}$

Washington accepted Hamilton's arguments and did not veto the bank bill (Holdsworth 19). The nation got a national banknote currency that circulated alongside the increasing plethora of banknotes issued by state-chartered banks. Perhaps Madison could have stopped the First Bank of U.S. if he had made his notes of the Convention public. Why didn't he? Honor and the pledge to keep Convention deliberations nonpublic may have trumped any desire to stop constitutionally questionable acts (Farrand I, 15; II, 648).

\section{Why Did They Do It?}

Before the U.S. Constitution, inside paper money was issued by state and national legislatures. After the U.S. Constitution, both state and national legislatures were banned from issuing paper money. Government-chartered, but privately run and largely 
unregulated, banks filled the void. After 1789 the U.S. experienced an increasing plethora of different banknote paper currencies. Judging by this outcome, the founding fathers did not intend to constitutionally create a single uniform national paper currency or prevent states and their banks from competing for seignorage with each other (Grubb 2003, 1782; Rolnick, Smith, and Weber). And if the founding fathers are assumed not to be stupid, or ignorant, or inexperienced in monetary matters, if they are assumed not to be fooled by the difference between binding legal tender laws and paper money emission per se, if they are assumed not to have confused war with peacetime monetary performance, and if they are assumed not to have deliberately written a deceitful Constitution-intending to ratify one meaning but execute another - then many of the explanations offered in the literature and by the delegates themselves are ruled out. ${ }^{31}$ So then, why did they do it? A. Rent-Seeking Bankers?

Grubb (2003, 2005a) argued that it was the Convention's banking faction, e.g. Langdon, Baldwin, King, Hamilton, Gerry, McHenry, the entire Pennsylvania delegation, and maybe a few others, who wanted an absolute Constitutional ban on the emission of paper money by both state and national governments so as to constitutionally eliminate competition with banknotes over what would become the dominant paper medium of exchange (see also Ferguson 1969; 1983, 402, 404, 409-10; Nettels 85). Banknotes were having a hard time supplanting government-issued paper money as the paper medium of exchange. With government-issued paper money constitutionally eliminated, the power and profitability of these banks, especially of the national banks, such as the Bank of North America and subsequently the First Bank of the U.S., were substantially increased. ${ }^{32}$ While consistent and plausible, and explaining why the founding fathers 
focused on paper money emission per se at both the national and the state level rather than just focusing narrowly on the problem of binding legal tender or just on state paper money, it does not explain the concurrence of those founding fathers with no apparent banking connections. Unless these other founding fathers were duped or arm-twisted by the banking faction, something more is needed.

Making the banking-faction argument more pervasive requires additional motives, such as founding fathers not enamored of national banking or directly involved with state banks may still have been in favor of local financial control. They may have wanted to achieve economic development at a more targeted local level than what state-macromoney policies could achieve. This view is consistent with the Convention not restricting or even debating state power to charter local banks but banning state-issued bills of credit, and leaving the national government's power to charter banks, at best, ambiguous. More research is needed, however, before the strength of this argument can be gauged. B. Big Tents, Polarization, Insider Speculation, and Income/Debt Redistribution Schemes?

Perhaps the founding fathers thought that the only way to stop binding legaltender issues of paper money was to ban all emissions of paper money, even non-legal tender emissions. Certainly much of the Federalist rhetoric cited above conflates paper money emissions per se with binding legal tender laws or considers the latter to be a consequence of the former. ${ }^{33}$ This is the "big tent" theory of legal proscription, e.g. it is not enough to ban murder, all the instruments that might be used to murder must also be banned. 
This explanation seems unlikely. First, the late colonial system had worked well with only a ban on legal tender paper money and not on all paper money. Second, the Convention did not ban other instruments that states had in the past made a legal tender. Third, the founding fathers did not pursue this theory on other, arguably more important, legal proscriptions put in the Constitution. For example, one of the key reasons for holding the Convention was to regulate trade between the states. As such, the founding fathers sought to prohibit states from taxing imports from, and exports to, other states. However, contrary to the "big tent" theory of Constitutional prescript, they allowed states to tax such imports and exports to support the execution of state-inspection laws (Farrand II, 605, 657), thus opening the door for states to erect cost wedges between products traded intra- versus inter-state, some of which were substantial (McCurdy). Finally, under this theory the founding fathers should have also banned banknotes or at least banned their acceptance as a legal tender. However, they did not do so. And Hamilton, as Secretary of the Treasury, simply declared that the notes of many banks were specie and therefore acceptable as legal-tender-like payments to the federal government (Syrett V, 394, 532-533; VI, 386-388; IX, 489).

After the Revolution, legislative polarization and civil unrest in many states, e.g. in Rhode Island, Massachusetts, Pennsylvania, Maryland, New Hampshire, and Virginia, had been linked by Federalist rhetoric to the popular rage for paper money (Farrand I, II; Grubb 2003, 1781; Holton 2004, 2005a, 2005b). If a goal of the Constitution was to eliminate polarizing political disputes within states, then banning state paper money rather than just restricting its legal tender status might make sense. If such were the case, why constitutionally ban federally issued paper money? In addition, under such a 
motivation the Constitution should have also banned banks, or have replicated something like the British Bubble Act as applied to the colonies in 1741. State banking laws were as much a source of political commotion as were paper money emissions. No other controversial state legislative issue was singled out for Constitutional proscription.

A popular explanation for why the Convention banned paper money per se has been that delegates held public securities and feared that they would not be redeemed at face value (in specie) if governments could issue paper money (Beard 178-188; Ferguson 1969; 1983; Holton 2004; McDonald 89-110; McGuire 72-74). This idea is also consistent with Morris' argument that the federal government should have the power to tax exports and so have direct access to tax revenue paid in specie. What scholars have missed in this debate is that this issue is only about binding legal tender laws and not about paper money emissions per se. If the Convention had simply banned paper money from being made a legal tender, securities denominated in specie would be protected against being paid off in depreciated paper money. Governments issuing paper money would have to pay their specie-denominated debts at the market exchange rate for their paper money. Creditors would incur no losses. Thus, efforts to link security holdings by Convention delegates with votes at the Convention for banning paper money may miss the mark.

The part of this public-securities argument that can be salvaged involves government securities denominated in that government's paper money. For such securities, governments could pay them off with newly issued paper money, even if that money was not a legal tender, because it was what was explicitly contracted. Security holders would receive the face value of the debt, though that value may have depreciated 
substantially from what it was at the time of contracting. This (unanticipated) inflation risk, however, was what any security holder faced no matter what monetary unit they contracted in—even specie. Market expectations governed price adjustments of said securities at the time of contracting. The gains or losses due to deflation or inflation would only be residual unanticipated luck. However, if governments were banned from issuing paper money then they would have to pay off their non-specie denominated securities in specie - the only money available. Because the courts would likely uphold contract "nominalism," this created the potential for speculative gains by Convention delegates and their confidants (Holton 2004; Priest). With the Convention deliberations kept secret, delegates would have superior information that soon governments would have to pay off their non-specie-denominated securities at par in specie. They would have had a head start on the market and could buy up government securities at their current discounted prices, knowing that the securities would appreciate in the near term. This motive would not show up as contemporaneous correlations between delegate security holding and Convention votes because such a speculative scheme had not yet been executed. Given that few government securities were denominated in that government's paper money, this motive seems unlikely.

Another explanation for why the founding fathers banned paper money is that government-issued non-specie backed paper money could be a tool of income redistribution. Independent of legal tender issues, income could be redistributed from creditors to debtors through altering values within non-specie denominated contracts via unanticipated inflationary issues of paper money. However, issuing depreciating state paper money was a clumsy redistribution scheme, and the founding fathers left intact 
other state powers that could be used to redistribute income that were more efficient at targeting benefits and easier to implement than paper money schemes (Nettels 85-86). At the Convention, Morris seemed to recognize that there were myriad ways of redistributing income via state laws that affected private contracts, and seemed not to care about these intra-state political machinations leading to mischievous income redistribution schemes (see Section V. B. above). Madison voiced a similar assessment when explaining the new Constitution to Jefferson in a letter written October 24, 1787-a month after the Convention had closed:

The mutability of the laws of the States is found to be a serious evil. The injustice of them has been so frequent and so flagrant as to alarm the most steadfast friends of Republicanism. ... The restraints agst. paper emissions, and violations of contracts are not sufficient. Supposing them to be effectual as far as they go, they are short of the mark. Injustice may be effected by such an infinitude of legislative expedients, that where the disposition exists it can only be controuled by some provision which reaches all cases whatsoever. The partial provision made, supposes the disposition which will evade it (Rutland X, 212).

\section{Creating a Specie Reservoir in Society for the Merchant Community Involved in}

\section{International Trade?}

Finally, a new reason will be offered here. While not all Convention delegates were directly connected to the nascent banking movement or holders of large amounts of public securities, most were connected in some way with the nation's international trading community (Beard; Bradford; McDonald; McGuire 51-54). Access to outside money, namely specie, was critical to the functioning of this trade. In general, specie flowed in from the trade surpluses with the Caribbean and flowed out with the trade deficits with Europe. With trade having to balance over the long run, specie would typically be available and the presence of a non-legal-tender tax-backed inside paper money would not threaten access to specie. The paper money that merchants received 
from local citizens in payment for goods, if not used to pay local taxes, could always be exchanged at the market-determined rates for specie when needed to meet outside payments. However, trade was not always balanced in the short run. Sometimes more specie flowed in than out, and at other times more flowed out than in. The former caused no merchant outside-payment problem. However, when more specie flowed out than in, merchants became desperate to find specie so as not to default on their outside-money contractual commitments_ - as the 1782-1789 recession made evident.

This problem could be solved if the merchant community could secure a reservoir of specie that could be tapped in times of short-run shortfalls in specie inflows and then filled back up again in times of short-run excess specie inflows. This was the idea behind the nascent merchant banks being developed at the time-having a "bank" of specie. If merchants dealing with international trade pooled their specie as deposits in said bank, then temporary short-run excesses and shortfalls in specie flows caused by the exigencies of trade could be smoothed across individuals within the community via intra-community short-term borrowing and lending. However, this could not stop large macro-trade shock from causing specie shortfalls and price depressions community wide, such as happened when Britain closed its Caribbean trade to the Americans shortly after 1783 (Bezanson 1951; Holton 2004; Rappaport).

The international-trading merchant community could secure a broader reservoir of specie in society at large from which they could draw in times of short-run shortfalls in specie inflows, if they could force the mass of citizens who were not directly engaged in international trade to nevertheless hold and use specie as their primary medium of exchange. They could only achieve this if they eliminated all non-specie-backed inside 
paper money. ${ }^{34}$ This meant eliminating the tax-backed paper money issued both by the states and by the federal government; in other words, constitutionally all money was either made outside money (specie) or was backed by outside money (banknotes) that were convertible into specie on demand. This is what the founding fathers got constitutionally, so maybe it was their overriding intent. This constitutionally manufactured revolution in governmental monetary powers was not about securing general monetary stability, but about securing narrower special interests (Grubb 2003; 2005a; McGuire).

In the end, society at large paid for serving as this specie reservoir. Given the exigencies of trade, during periods of short-run excess specie inflows, the public experienced credit expansion and suffered inflationary price rises and investment overextension. Then during periods of short-run shortfalls in specie inflows (relative to outflows), the public experienced credit contraction, money scarcity, and arguably the more costly effects of bankruptcies, deflation, and investment retrenchment. Banks, functioning as a money multiplier in this process, may have structurally amplified this short-run or cyclical pain inflicted on the public for being the merchant community's specie reservoir. An inside government-issued tax-backed paper money not directly linked to specie would likely have insulated and dampened the effects of international trade-flow specie shocks on the public. ${ }^{35}$ Luther Martin (and in an odd way Gouvernuer Morris) probably saw the issue correctly (Farrand II, 307; III, 214-215).

\section{Epilogue}

Today the U.S. has the same written Constitution in terms of monetary powers that the founding fathers created in 1787 . Yet we have a national paper money that is 
backed not by specie but only by federal government taxes, or the good faith and credit of the federal government — a government that also has power to institute price and exchange rate controls on said currency (Rockoff). This paper money is also a legal tender, with the legal tender clause "This note is legal tender for all debts, public and private" printed on each note. It is issued by the Federal Reserve Banking system that, while only a quasi-government agency in the strict legal sense, is about as close to a national banking system incorporated by the federal government as one can get. Unless we take the original intent of the founding fathers in their debates and votes at the 1787 Convention on monetary/banking powers to be a devious ruse, then it is hard not to conclude that we have strayed far away from what they tried to prohibit constitutionally. ${ }^{36}$ 


\section{REFERENCES}

Adams, Randolph G., ed., Selected Political Essays of James Wilson. New York: Alfred A. Knopf, 1930.

Baack, Ben, "Forging a Nation State: The Continental Congress and the Financing of the War of American Independence." Economic History Review 54(4), Nov. 2002, pp. 639656.

Beard, Charles A., An Economic Interpretation of the Constitution of the United States. New York: The Free Press, 1986.

Behrens, Kathryn L., "Paper Money in Maryland 1727-1789." Johns Hopkins University Studies in Historical and Political Science 41(1), 1923, pp. 9-98.

Bezanson, Anne, et al., Wholesale Prices in Philadelphia, 1784-1861. Philadelphia: University of Pennsylvania Press, 1936.

Bezanson, Anne, Prices and Inflation during the American Revolution: Pennsylvania, 1770-1790. Philadelphia: University of Pennsylvania Press, 1951.

Bishop, Hillman Metcalf, "Why Rhode Island Opposed the Federal Constitution." Rhode Island History 8(1), Jan. 1949, pp. 1-10; 8(2), Apr. 1949, pp. 33-44; 8(3), Jul. 1949, pp. 85-95; 8(4) Oct. 1949, pp. 115-126.

Bradford, M. E., Founding Fathers: Brief Lives of the Framers of the United States. Lawrence, KS: University of Kansas Press, 2nd Edn., 1994.

Brock, Leslie V., The Currency of the American Colonies, 1700-1764. New York: Arno Press, 1975.

Bordo, Michael D., and Ivan A. Marcotte, "Purchasing Power Parity in Colonial America: Some Evidence for South Carolina 1732-1774." Carnegie-Rochester Conference Series on Public Policy 27, Autumn 1987, pp. 311-324.

Bouton, Terry, "Tying Up the Revolution: Money, Power, and the Regulation in Pennsylvania, 1765-1800.” Unpublished PhD Dissertation, Duke University, 1996.

Bryan, Alfred Cookman, "History of State Banking in Maryland." Johns Hopkins University Studies in Historical and Political Science 17(1-3), 1899, pp. 1-144.

Calomiris, Charlie W., "Institutional Failure, Monetary Scarcity, and the Depreciation of the Continental." Journal of Economic History 48(1), Mar. 1988, pp. 47-68.

Cole, Arthur Harrison, Wholesale Commodity Prices in the United States, 1700-1861. Cambridge, MA: Harvard University Press, 1938. 
Elliot, Jonathan, ed., The Debates in the State Conventions on the Adoption of the Federal Constitution as Recommended by the General Convention at Philadelphia in 1787. Philadelphia: J.B. Lippincott Co., 1836.

Farrand, Max. ed., The Records of the Federal Convention of 1787. New Haven, CT: Yale University Press, Vols. 1-4, 1966.

Feldstein, Martin, ed., Economic and Financial Crises in Emerging Market Economies. Chicago: University of Chicago Press, 2003.

Ferguson, E. James, "The Nationalists of 1781-1783 and the Economic Interpretation of the Constitution." Journal of American History 56(2), Sept. 1969, pp. 241-261.

Ferguson, E. James, "Political Economy, Public Liberty, and the Formation of the Constitution." William and Mary Quarterly 3rd Ser., 40(3), July 1983, pp. 389-412.

Freeman, Joanne B., ed., Alexander Hamilton: Writings. New York: The Library of America, 2001.

Gras, N. S. B., The Massachusetts First National Bank of Boston, 1784-1934. Cambridge, MA: Harvard University Press, 1937.

Grubb, Farley, "Creating the U.S. Dollar Currency Union, 1748-1811: A Quest for Monetary Stability or a Usurpation of State Sovereignty for Personal Gain?" American Economic Review 93(5), Dec. 2003, pp. 1778-1798.

Grubb, Farley, "The Circulating Medium of Exchange in Colonial Pennsylvania, 17291775: New Estimates of Monetary Composition, Performance, and Economic Growth." Explorations in Economic History 41(4), Oct. 2004, pp. 329-360.

Grubb, Farley, "The Constitutional Creation of a Common Currency in the U.S., 17481811: Monetary Stabilization versus Merchant Rent Seeking," in Jurgen Nautz and Lars Jonung, eds., Conflict Potentials in Monetary Unions. [Beihefte der Vierteljahrshefte fur Sozial-und Wirtschaftsgeschichte]. (Stuttgart: Steiner Verlag, 2005a, forthcoming.

Grubb, Farley, "Testing for the Economic Impact of the U.S. Constitution: Purchasing Power Parity across Six British Colonies Versus across the Same Six U.S. States, 17481811." Unpublished working paper, Economics Dept., University of Delaware, 2005b.

Holdsworth, John Thom, The First Bank of the United States. [Senate Document No. 571, 61st Congress, 2nd Session] Philadelphia: National Monetary Commission, 1910.

Holton, Woody, "'From the Labours of Others': The War Bonds Controversy and the Origins of the Constitution in New England." William and Mary Quarterly 61(2), Apr. 2004, pp. 271-316. 
Holton, Woody, “'Divide et Impera': Federalist 10 in Wider Sphere." William and Mary Quarterly 62(2), Apr. 2005a, pp. 175-212.

Holton, Woody, "Did the Constitution Save the Economy?" Journal of American History $42,2005 \mathrm{~b}$, forthcoming.

Hutson, James H., ed., Supplement to Max Farrand's The Records of the Federal Convention of 1787. New Haven, CT: Yale University Press, 1987.

Jensen, Merrill, ed., The Documentary History of the Ratification of the Constitution. Madison, WI: State Historical Society of Wisconsin, Vols. 1-3, 1976-1978.

Lewis, Lawrence, Jr., A History of the Bank of North America. Philadelphia: J. B. Lippincott, 1882.

Main, Jackson Turner, The Antifederalists: Critics of the Constitution, 1781-1788. New York: W.W. Norton, 1961.

McCurdy, Charles W., "American Law and the Marketing Structure of the Large Corporation, 1875-1890.” Journal of Economic History 38(3), Sept. 1978, pp. 631-649.

McCusker, John J., Money and Exchange in Europe and America, 1600-1775. Chapel Hill, NC: University of North Carolina Press, 1978.

McDonald, Forrest, We the People: The Economic Origins of the Constitution. New Brunswick, NJ: Transaction Publishers, 1992.

McGuire, Robert A., To Form a More Perfect Union: A New Economic Interpretation of the United States Constitution. New York: Oxford University Press, 2003.

Meigs, William M., The Growth of the Constitution in the Federal Convention of 1787. Philadelphia: J. B. Lippincott, 1900.

Muhlenman, Maurice, Monetary Systems of the World. New York: Charles H. Nicoll Publisher, 1895.

Nettels, Curtis P., The Emergence of a National Economy, 1775-1815. New York: Harper \& Row, 1962.

Nevins, Allan, The American States During and After the Revolution, 1775-1789. New York: Macmillan Co., 1924.

New Jersey Gazette, Jan. 30, 1786. 
Philoeunomos [Sherman, Roger], A Caveat Against Injustice or an Enquiry into the Evil Consequences of a Fluctuating Medium of Exchange, Wherein is Considered, Whether the Bills of Credit on the Neighbouring Governments, are a Legal Tender in Payments of Money. New York: Printed by Henry De Forrest, 1752.

Pennsylvania Archives, 8th Series, Vol. 4, 1931.

Pennsylvania Herald and General Advertiser, July 14, 21, and 25 of 1787.

Perkins, Edwin J., American Public Finance and Financial Services, 1700-1815.

Columbus, OH: Ohio State University Press, 1994.

Pickering, Danby, The Statues at Large from the Magna Charta to the End of the Eleventh Parliament of Great Britain, Anno 1761. Cambridge, UK: J. Bentham, Vol. 20, 1765.

Priest, Claire, "Currency Policies and Legal Development in Colonial New England." The Yale Law Journal 110(8), June 2001, pp. 1303-1405.

[Randolph, Peyton], A Letter to a Gentleman in London from Virginia. Williamsburg, VA: Printed by William Hunter, 1759.

Rappaport, George David, Stability and Change in Revolutionary Pennsylvania.

University Park, PA: Pennsylvania State University Press, 1996.

Redish, Angela, "Why Was Specie Scarce in Colonial Economies? An Analysis of the Canadian

Currency, 1796-1830.” Journal of Economic History 44(3), Sept. 1984, pp. 713-728.

Rockoff, Hugh, Drastic Measures: A History of Wage and Price Controls in the United States. New York: Cambridge University Press, 1984.

Rolnick, Arthur J., Smith, Bruce D., and Weber, Warren E., "In Order to Form a More Perfect Monetary Union.” Federal Reserve Bank of Minneapolis Quarterly Review 17(4), Fall 1993, pp. 2-9.

Rutland, Robert A., ed., Papers of George Mason. Chapel Hill, NC: University of North Carolina Press, Vol. 2, 1970.

Rutland, Robert A., ed., Papers of James Madison. Charlottesville, VA: University Press of Virginia, Vols. 8-14, 1973-1983.

Schweitzer, Mary M., "State-Issued Currency and the Ratification of the U.S. Constitution." Journal of Economic History 49(2), June 1989, pp. 311-322. 
Smith, Bruce, "Some Colonial Evidence on Two Theories of Money: Maryland and the Carolinas.” Journal of Political Economy 93(6), Dec. 1985, pp. 1178-1211.

Smith, James Morton, ed., The Republic of Letters: The Correspondence Between Thomas Jefferson and James Madison, 1776-1826. New York: W. W. Norton, Vol. 1, 1995.

Smyth, Albert H., ed., The Writings of Benjamin Franklin. New York: Macmillan Co., Vol. 9, 1907.

Syrett, Harold C., ed., Papers of Alexander Hamilton. New York: Columbia University Press, Vols. 2-10, 1961-1966.

Warren, Charles, The Making of the Constitution. Littleton, CO: Fred B. Rothman, 1993.

Webster, Pelatiah, Political Essays. New York: Burt Franklin, 1969 [originally 1791].

Wilson, Janet, "The Bank of North America and Pennsylvania Politics: 1781-1787." Pennsylvania Magazine of History and Biography 66(1), Jan. 1942, pp. 3-28. 


\section{FOOTNOTES}

${ }^{1}$ From May 28th through September 17 th the delegates met every day except Sundays. There was a brief adjournment on the 4th of July, from July 27th through August 5th while the Committee of Detail crafted a draft constitution, and on September 11th while the Committee on Style polished the draft (Farrand I, II). Not all States or delegates attended continuously, see Farrand (III, 557-559, 586-590).

2 The "inside" versus "outside" money distinction is important. Outside money (specie) is that used to clear international (trans-government-jurisdictional) debts for both private and public trades. For a nation that did not produce specie, such as the U.S. in 1787 , to have its money supply be only outside money meant that specie had to be imported to serve as the domestic money supply, which only could be done by exporting goods to import this money, thus sacrificing the importation of other real goods. It also meant that the government had little direct influence over domestic monetary policy (other than regulatory powers over foreign trade), and that the economy was exposed to short-run swings in the availability of money (specie) caused by the exigencies of trade flows, wars, etc. These short-run swings could put severe pressure on domestic transactions, debt recovery, and tax revenues. The gain from using only outside money was that, in the long run, international markets would equilibrate. Specie would flow from where it was plentiful to where it was scarce, leading to a common long-run stability in price trends internationally (Redish 713-714). Long-run domestic inflation would be constrained to be similar to long-run inflation in the outside money internationally. By contrast, when an inside money (not directly linked to specie) is used in place of outside money for purely domestic transactions, debt recovery, and tax 
payments, it frees the outside money to buy imported real goods thus increasing social welfare (Pennsylvania Archives IV, 3284). It also increases the income (seignorage) of the government issuing the inside money - a non-inflationary substitute for direct tax revenue. The government would pay for goods with the initial issue of the inside money that would then circulate in society as currency, and/or loan out said money at interest to its citizens. Issuing an inside money also gave the government a short-run monetary policy instrument to counter swings in economic activity caused by the exigencies of trade flows, wars, and other international disruptions to the outside money supply. The government could issue more inside money than it taxed out of circulation or vice versa to counterbalance short-run swings in the availability of outside money (Ferguson 1983, 399-400; Grubb 2003, 1780, 1792). Having an inside money also insulated purely domestic transactions, debt recovery, and tax payments from money scarcity caused by excessive short-run specie outflows due to short-run imbalances in trade flows. The market exchange rate between the inside and outside money, and thus the international merchant trading community as opposed to the whole society, would be forced to absorb the brunt of monetary shocks generated by the short-run imbalance in specie flows caused by the exigencies of trade, wars, etc. When only outside money is used, these short-run shocks are borne by the entire society and sometimes disproportionately by purely domestic traders. The cost of using an inside money is the temptation to engage in unanticipated inflationary finance by over-issuing it, thus inflating prices in the inside money faster than prices in the outside money and so (unexpectedly) driving the exchange rate between inside and outside money down. The typical causes are popular politics - promising more government services than the people are willing to pay for with 
taxes - and emergency expenditures such as during wars. The exchange rate between inside and outside money is the disciplining tool to restrain governments from excess inflationary finance. The legal tender issue (discussed later) becomes economically important when governments try to escape this discipline by legally mandating the exchange rate between the inside and outside money to be different from that determined by the market. For an up-to-date discussion for contemporary economies, see Feldstein $(1-92)$.

${ }^{3}$ The only enumerated monetary power given Congress by the U.S. Constitution was the power to "coin money, regulate the value thereof, and of foreign coin" [Article 1 Section 8]. Congress could declare what its official monetary unit of account would be, as it did in July of 1785-well before the Constitutional Convention — when it declared the dollar to be the official unit of account for the national government. But Congress could not constitutionally force others engaged either in private or state transactions to use a specific monetary unit of account. State-chartered banks could have issued their banknotes in monetary units other than U.S. dollars. The Constitution's prohibition on states issuing bills of credit and making anything other than gold and silver a legal tender would not necessarily force a common monetary unit of account on the country for it allowed any specie unit of account to be used in legal tender transactions. While the national government did mint U.S. dollar coins after 1792, foreign coins of various denominations - Spanish silver dollars, Spanish gold pistoles, Portuguese Johannes, English silver shillings, etc.-- remained in circulation for some time, and nothing legally stopped people from selecting any of these other foreign specie denominations as a monetary unit of account. Even regarding the legal tender that the Federal Government 
would accept there was no necessary or legally forced common unit of account in the early Republic. Congress by act of February 9, 1793 made the gold coins of Great Britain, France, Spain, and Portugal and the silver coins of France and Spain a legal tender. This act was frequently renewed, e.g. in $1798,1806,1819,1821,1823,1834$, and 1843. Not until the act of February 21, 1857 did Congress repeal all laws making foreign coins a legal tender in the United States (Muhleman 39).

${ }^{4}$ A common error repeated often in the literature is the claim that the Convention intentionally crafted a Constitution where Congress was allowed the power to emit bills of credit. For example, see Baack (653); Ferguson (1969, 254, 258); Nettels (98-99); Rolnick, Smith, and Weber (3); Schweitzer (311). The analysis here, if nothing else, is a valuable corrective in showing that under almost any logically consistent and coherent interpretation such a claim cannot be easily sustained. See also footnote 23 .

${ }^{5}$ I will rely primarily on Convention records and supporting documents as compiled in Farrand (I, II, III), and on his interpretation of those records and documents. The most detailed records of the debates at the Convention are the notes taken by James Madison. These "...have remained the standard authority for the proceedings of the Convention" (Farrand I, xvi). As such, unless otherwise indicated, quotations of Convention debates are taken from Madison's notes. At the Convention, votes on motions were recorded by state, not by individual delegate. Thus, when votes are reported in the text, e.g. 8 to 3 against, they refer to the number of states on either side of the issue.

${ }^{6}$ Hamilton's argument here is basically the same as that made by Charles Pinckney at the opening of the Convention that initially found its way into an early draft of the 
Constitution made by the Committee of Detail—only to be abandoned for more radical proscriptions, see Section II. B., and Section IV. below.

${ }^{7}$ On May 29th while taking notes on Randolph's speech James McHenry of Maryland jotted down, "Congress ought to possess a power to prevent emissions of bills of credit" (Farrand I, 26). Was McHenry quoting Randolph's speech or was this phrase simply McHenry's own sentiment expressed in his notes? The evidence strongly points against the former and in favor of the latter interpretation. First, this phrase, or anything like it, does not appear in the Convention's Journal or in the notes taken by Madison, or by Robert Yates (New York), or by William Patterson (New Jersey) for that day. Second, the phrase in question, or anything like it, does not appear in Randolph's own text of the speech. Randolph provided the written text of his speech to Madison who substituted it in place of his notes on the speech (appearing in Randolph's handwriting in Madison's notes of the Convention for that day). Third, the phrase in question was jotted down by McHenry in an odd location, namely in the section where Randolph was talking about blessings that the National Congress could bestow on the union if only it was given its own power of taxation (as opposed to appearing in the section which addressed the disharmony and conflict among the States). Thus, one possible interpretation of McHenry's phrasing is that, given its own power to tax, Congress would not have to resort to emissions of paper money as it did during the Revolution. In other words, McHenry simply deduced that Congress ought to possess the power to tax that in turn would mean that they would possess the power to prevent themselves from engaging in emissions of bills of credit. Finally, McHenry's notes for other days frequently contain his own assessments and views in addition to recording some of the day's discussions 
among the delegates. Thus, another likely interpretation would be that the phrase in question was an expression of McHenry's own personal desires. McHenry had recently sponsored a bill in the Maryland State Senate for establishing a bank. The Maryland House of Delegates had repeatedly blocked this bill. In its place the Maryland House of Delegates had passed a bill for a new emission of Maryland State paper money. In turn, the Maryland Senate had repeatedly blocked this paper money bill. McHenry may have seen a national congressional power to ban state paper money as the solution to this stalemate between the banking faction and the state paper-money faction that would allow his banking bill to succeed. See Bryan (17-19); Behrens (79-97); Grubb (2003, 1788-1789).

${ }^{8}$ It should be noted that the New York State Assembly debated the same issue early in 1787 regarding how the states would pay for Congress' proposed Continental Impost (national tariff). If each state could pay the national government in its respective paper money at the face value of that money in specie, rather than at its market value in specie, then specie-value inequities in tax contributions would occur between states to the extent that state paper monies traded at different market values off their face value in specie. For example, in his address to the New York Assembly in February of 1787 Alexander Hamilton argued, "The paper money of the state of New-York, in most transactions is equal to gold and silver - that of Rhode-Island is depreciated to five for one - that of North-Carolina to two for one - that of South-Carolina may perhaps be worth fifteen shillings in the pound. If the states pay the duties in paper [at their face value and not their market value], is it not evident that for every pound of that duty consumed by the citizen of New-York he would pay 20s. [shillings] while the citizen of South-Carolina 
would pay 15s. [shillings] of North-Carolina, 10s [shillings] and Rhode-Island, only four [shillings]!” (Syrett IV, 87). The source of Hamilton's problem was binding legal tender laws and not the emission of paper money per se.

${ }^{9}$ On June 2nd during the debate over how to elect the national executive, Elbridge Gerry of Massachusetts also opined that "he thought the Community not yet ripe for stripping the States of their powers, even such as might not be requisite for local purposes" (Farrand I, 80).

${ }^{10}$ Randolph's opening speech on May 29th only referred to the "havoc of paper money." As such, it may have only been referring to the debacle of the national government's paper Continental dollar.

${ }^{11}$ Hamilton's notes for June 6th also mention paper money. His notes, however, are cryptic and lacking in context, and so their meaning is hard to interpret. He wrote, "Paper money is capable of giving a general impulse. It is easy to conceive a popular sentiment pervading the E states_-" (Farrand I, 146-147).

12 Among Sherman's papers is a document outlining proposals for a plan of government which includes the following: "That the legislature of the individual states ought not to possess a right to emit bills of credit for a currency, or to make any tender laws for the payment or discharge of debts or contracts, in any manner different from the agreement of the parties, unless for payment of the value of the thing contracted for, in current money, agreeable to the standard that shall be allowed by the legislature of the United States, or in any manner to obstruct or impede the recovery of debts, whereby the interests of foreigners, or the citizens of any other states, may be affected" (Farrand III, 616). When this plan was written and to whom it was shown is difficult to determine. No 
specific reference to it appears in the Convention debates. Farrand (III, 615) suggests that it represented the ideas of the Connecticut delegation in forming the New Jersey Plan. However, nothing like the above passage appears in the New Jersey Plan, and it was not among the documents referred to the Committee on Detail on July 26th.

${ }^{13}$ The reference here is to the paper money emitted by Rhode Island in 1786. A major complaint against this action by out-of-state creditors came when Rhode Island made this paper money a legal tender, because it meant that out-of-state creditors would have to accept Rhode Island paper money for payment of loans made within Rhode Island. The retaliation of which Madison speaks were laws passed by the Connecticut and Massachusetts legislatures that allowed their citizens, respectively, who owed debts to Rhode Island creditors to pay their debts in Rhode Island in Rhode Island paper money (Grubb 2003, 1782).

${ }^{14}$ Hamilton made almost the same confession in 1790 as Secretary of the Treasury in his Report on a National Bank in reference to the peacetime stability of state-issued paper money. He said, "The emitting of paper money by the authority of Government is wisely prohibited to the individual States, by the National Constitution. ... In times of tranquility, it [state-issued paper money] might have no ill consequences, it might even perhaps be managed in a way to be productive of good; but in great and trying emergencies, there is almost a moral certainty of it becoming mischievous" (Freeman 591-592).

${ }^{15}$ Luther Martin, Convention delegate from Maryland, made similar observations (Farrand III, 214-215). 
${ }^{16}$ See also footnote 4 above and footnote 25 below. McHenry's notes for this day corroborate the Convention's decision to strike the words "and emit bills" from the powers granted to the federal government (Farrand II, 311). Shortly after the Convention, at the South Carolina ratification debate, Pinckney said, "Besides, if paper should become necessary, the general government still possess the power of emitting it, and Continental paper, well funded, must ever answer the purpose better than state paper" (Elliot 335). While Pinckney did not speak on the day (August 16th) when the Convention voted to ban the national government from emitting bills of credit, he did speak on August 15th and again on August 17th and is thought to have been present on August 16th. And South Carolina was recorded as voting for this ban on August 16th (Farrand II, 298, 304-310, 314; III, 589-590). Whether Pinckney had forgotten or was strategically lying is hard to say. Pinckney's claim also illustrates the key problem with the Constitution's construction that would prove so controversial regarding a national bank (see Section VI. B.). Powers explicitly voted not to be given the national government were not written in the Constitution.

${ }^{17}$ Absolutely prohibiting government-issued paper money in the Constitution was considered a high-risk, all-or-nothing, less-than-popular move. Those who most advocated it, such as Morris and Wilson, while not directly connecting it with the issue of how to get the Constitution ratified, took a position on ratification seemingly consistent with this high-risk strategy. For example, Wilson argued for approval of only 7 out of the 13 states for the new Constitution to be adopted and put into operation in place of the Articles of Confederation. Considering that 6 of the 13 states had so far won the political battle within their respective states against issuing paper money after the Revolution, and 
that anti-paper money forces had recently gained control of Pennsylvania's political process, the number that Wilson advocated to achieve ratification is telling (Farrand II, 468, 477, 562; Grubb 2003, 1790).

${ }^{18}$ Gouverneur Morris could have meant something like the personal notes issued by Robert Morris during the Revolution as Congress' Superintendent of Finance. Given the close relationship between these notes and those soon issued by Robert Morris' Bank of North America, the distinction is probably minor (Perkins 115-116). It is hard to conclude that Morris meant any other than the Bank of North America here by the term "responsible minister." The only approximate national paper currency being issued between 1782 and 1787 were the banknotes of Morris' Bank of North America.

${ }^{19}$ In a footnote to his notes on the Convention written sometime after the War of 1812 Madison explained Virginia's affirmative vote for Morris' motion to delete "and emit bills on the credit of the United States" despite the objections raised by the Virginia delegates Randolph, Mason, and himself, as "This vote in the affirmative by Virga. Was occasioned by the acquiescence of Mr. Madison who became satisfied that striking out the words would not disable the Govt from the use of public notes as far as they could be safe $\&$ proper; $\&$ would only cut off the pretext for a paper currency and particularly for making the bills a tender either for public or private debts" (Farrand I, xv-xix; II, 310). This explanation may be a hindsight effort by Madison to cover himself for the problems he and the national government faced during his presidency in financing the War of 1812 given no constitutional power to emit bills of credit and given that the charter of the First Bank of the U.S. had lapsed in 1811 (Perkins 324-348). 
${ }^{20}$ On August 28th Pinckney moved again to add the power to the national legislature to negate all state laws interfering with the harmony of the union. This power had already been defeated by the Convention on July 17 th and would not be adopted at this time either (Farrand II, 27-28, 382, 390-392). Because the draft constitution submitted by the Committee of Detail already explicitly gave the national legislature the power to negate state emissions of paper money, giving the national legislature a general negative over state laws is not relevant to the issue of monetary powers here as it was before August 6th. But Pinckney's move here does indicate that the prior demand for a general negative over state laws was not just a disguised demand for a negative over state-issued paper money.

${ }^{21}$ An interesting question is whether the order of the vote mattered to the outcome in an agenda control interpretation. The vote on whether to absolutely prohibit state bills of credit was taken first and then the vote on whether to prohibit making anything but gold and silver legal tender was taken second. Given some doubt about the outcome of the second vote, a delegate may have been induced to vote in favor of absolute prohibition on the first vote. By contrast, had the second vote been taken first with the same outcome so that all the delegates knew that states could not make their paper money a legal tender, then the outcome of the (now) second vote on whether to absolutely prohibit state bills of credit might have been different, in effect being only a vote over allowing a non-legal tender paper money as opposed to the original vote which was over allowing paper money in general.

${ }^{22}$ During the South Carolina's ratification debate, Pinckney argued (Elliot 333-336), "This section [Articles 1, Section 10 restricting State sovereignty] I consider to be the 
soul of the Constitution,... The only parts of this section that are objected to are those which relate to the emission of paper money, and its consequence, tender-laws, and the impairing the obligation of contract." He then goes on for several pages defending the Constitution's absolute ban on state paper money. Apparently, Pinckney expected the strongest opposition to ratification to come from this single clause. During the ratification debates, Martin objected strenuously to the absolute ban on state paper money, claiming that it was because the Convention was "...smitten with the paper money dread,..." Martin "considered that this State [Maryland], and some others, had formerly received great benefit from paper emissions,... [that] such emissions might hereafter be equally advantageous; and further, that it is impossible to foresee, that events may not take place, which shall render paper money of absolute necessity..." (Farrand III, 214-215). Finally, Main (1961, pp. 268-279) argued that many Americans, maybe even a majority, were on the side of paper money and unhappy with the Constitution over absolutely banning its emission (see also Holton 2005a, 198):

This thesis....stressed the correlation between Antifederalism and paper money... This interpretation has much truth. ... It is also true...that paper money was a factor in the [ratification] contest. In Massachusetts, towns opposing paper were Federal by about four to one, while pro-paper money towns were Antifederal by an even wider margin. [footnote 58: Pro-paper money towns cast only 3 votes for and 22 votes against ratification; anti-paper money towns favored ratification 29 to 7.] The hard (or less soft) money towns in New Hampshire were Federal; most of the Antifederal strength in Connecticut was found in paper money districts; and the case of Rhode Island is sufficiently familiar. ... In Maryland and Virginia the paper money forces opposed ratification. This was also the case in North Carolina, while in South Carolina, Antifederal strength lay in the backcountry, which had favored inflation. ... All the foregoing does not prove an exact correlation... There are...exceptions... Leaving aside the fact that many Antifederalist, especially the leaders, specifically denounced state currency emissions, we have to consider the following exceptions: (1) in South Carolina, a large number of planters, most of whom became Federalist, supported paper emission; ... (4) New Jersey endorsed both paper money and the Constitution; (5) 
in Pennsylvania, although it is probable that a majority of the people were Federal, a majority favored paper money... That paper money sentiment was in some degree a factor in the existence of Antifederalism is scarcely to be doubted - the Antifederalists drew more heavily by far than their opponents from the ranks of paper money advocates...

${ }^{23}$ This interpretation was restated explicitly in the 10th Amendment to the Constitution adopted in 1791. By contrast, and in direct contradiction to the 10th Amendment, some scholars often assert that the federal government can do anything it wants under the Constitution as long as the Constitution does not explicitly prohibit it (the modern Federalist view?). This interpretation renders Article 1 Section 8 of the Constitution superfluous and nonsensical. It makes many of the debates and votes at the Constitutional Convention equally superfluous and nonsensical, such as the debate and decision to state specifically in the Constitution that Congress has the explicit positive power to establish post offices but voting not to state specifically that Congress has the explicit power to establish a university (Farrand II, 611, 616, 620).

${ }^{24}$ For example, the Constitution explicitly grants Congress the power to establish post offices and post roads. If the founding fathers had considered that the power to establish post offices implied the power to establish post roads to carry the mail between post offices, then no separate granting of power to establish post roads would have been required in the Constitution. Explicitly enumerating such a power separately implies that the founding fathers did not consider that the power to establish post roads was implied by the power to establish post offices. The logic of such comparisons circumscribes the implied powers clause in Article 1 Section 8. As such, the power to establish post offices would not imply that Congress also has the power to go into the business of breeding horses for post riders. 
${ }^{25}$ Scholars have often been deflected by this implied-powers argument for federal power both to issue bills of credit and to charter banks without considering what was meant by explicit Convention votes not to grant the federal government these powers. For example, see Nettels (99).

26 "ca" can be an abbreviation for "chartered accountancy," but how that applies here is unclear.

${ }^{27}$ The following is Madison's description of how he took notes at the Convention: "I chose a seat in front of the presiding member, with the other members, on my right and left hand. In this favorable position for hearing all that passed I noted in terms legible and in abbreviations and marks intelligible to myself what was read from the Chair or spoken by the members; and losing not a moment unnecessarily between the adjournment and reassembling of the Convention I was enabled to write out my daily notes during the session or within a few finishing days after it closed" (Farrand I, xvi).

${ }^{28}$ Because New York did not vote at the Convention after July 10th, Hamilton may not have paid close attention to specific debates even when he was in attendance. Robert Yates and John Lansing, the other delegates from New York, left the Convention by July 10th and did not return (Farrand).

${ }^{29}$ Hamilton's role here is difficult to fathom, in particular his silence during the Convention on the issue of banks, especially on the crucial day in question-September 14th. None of Hamilton's recorded statements at the Convention, including his plan of government, mention banks (Farrand). However, before the Convention, Hamilton had long advocated that the national government be given the power to charter banks (Freedman 76-77; Holdsworth 9-19). After the Convention as Secretary of the Treasury, 
Hamilton was the chief proponent of Congress' right to charter a national bank (Freeman 575-646). Reconciling Hamilton's very active argumentation and pursuit of a national bank both before and after the Convention with his silence during the Convention is hard to do without regarding Hamilton as being strategically cunning and deceptive (Ferguson 1983, 404-405; Grubb 2003, 1791). Perhaps Hamilton considered banking so controversial an issue that any positive mention might excite too much opposition at the Convention-killing the Constitution's chances of ratification. Perhaps Hamilton thought if he "played possum" he could get his way no matter what the Convention intended as long as the Convention did not absolutely ban national banking by written clause in the Constitution.

30 In a letter to Madison, dated June 20, 1791, George Nicholas concluded, "The Bank \&c. [First Bank of the U.S.] prove that paper barriers [the U.S. Constitution] are very weak; could it have been foreseen that no greater regard would have been paid them many federalists would have been the warmest opposers of the government" (Rutland XIV, 33).

${ }^{31}$ Ferguson $(1969,1983)$ emphasizes the federal debt as the driving force behind the constitutional agenda of the nationalists. The debt problem, however, was solved by giving the federal government the independent power to tax and by the transfer of state lands claimed in the west to the federal government - moving the federal government toward a solvent position asset-wise. With the exception of legal tender restrictions, paper money and banks were separable issues to funding the debt and so funding the federal debt cannot explain the particular monetary powers chosen to be in the Constitution.

${ }^{32}$ For example, as early as 1780 Hamilton, in a letter to James Duane, confided, 
And why can we not have an American bank? Are our monied men less enlightened to their own interest or less enterprising in the persuit? I believe the fault is in our government which does not exert itself to engage them in such a scheme. ... The only certain manner to obtain a permanent paper credit is to engage the monied interest immediately in it by making them contribute the whole or part of the stock and giving them the whole or part of the profits (Freeman 83-84).

See also the letter from William Bingham, a director of the Bank of North America, to Hamilton on November 25, 1789, where he advises Hamilton to establish a national bank, that such a bank would receive "great Benefit \& Emolument" from this situation, and that the Bank of North America would be a good candidate for being the national bank (Syrett $\mathrm{V}$, 538-554).

${ }^{33}$ For example, during the South Carolina ratification debates, Pinckney referred to “...the emission of paper money and its consequences, tender-laws, and the impairing the obligation of contracts" (Elliot 334 [italics added]).

${ }^{34}$ For example, Pinckney's argument for constitutionally banning paper money made during South Carolina's ratification debates is consistent with this position (Elliot 334).

${ }^{35}$ For an up-to-date discussion of these issues for contemporary economies, see Feldstein (1-92).

${ }^{36}$ In the 19th century, the U.S. Supreme Court ruled that under the "Necessary and Proper" clause [the implied-powers clause] of the Constitution the federal government had the power to emit bills of credit and to incorporate a national bank, these powers being implied by other enumerated powers granted Congress (Warren 696, 700-701). Whether the Supreme Court determined that the "Necessary and Proper" clause trumped powers explicitly voted not to be included in the list of enumerated powers or whether 
they just redefined "Necessary and Proper" to be "Expedient and Desirous" is a story for another day. 